\title{
PILOT PLANT KOMBINASI BIOFILTRASI DENGAN ULTRAFILTRASI UNTUK PENYEDIAAN AIR MINUM
}

\author{
Combined Biofiltration-Ultrafiltration Pilot Plant For Dringking Water Supply \\ Oleh : \\ Wahyu Widayat \\ Pusat Teknologi Lingkungan, BPPT
}

\begin{abstract}
Abstrak
Kota-kota besar di Indonesia menggunakan air sungai sebagai air baku PAM (Perusahaan Air Minum). Konsentrasi senyawa organik dan amoniak di dalam air baku PAM terus meningkat akibat pencemaran limbah industri dan domestik. Kombinasi proses biofiltrasi dengan ultrafiltrasi merupakan salah satu alternatif untuk mereduksi konsentrasi senyawa organik, amoniak, besi, mangan dan kekeruhan di dalam air baku. Pengolahan menggunakan reaktor biofilter dengan media tipe sarang tawon dikombinasikan dengan ultrafiltrasi. Kondisi operasional pengolaan dengan variasi HRT (Hydraulyc Rentention Time) antara 1-4 jam dengan suplai udara 0-30 I/menit. Kondisi operasional terpilih adalah pada HRT 2 jam dan suplai udara $20 \mathrm{l} /$ menit yaitu dengan efisiensi konsentrasi organik, amoniak, besi, mangan, dan kekeruhan secara berturutturut adalah $68 \%$, $65 \%$, $68 \%, 67 \%$, dan $72 \%$.
\end{abstract}

Kata Kunci: Biofiltrasi, ultrafiltrasi, media tipe sarang tawon, efisiensi reduksi, air minum.

\begin{abstract}
In big cities of Indonesia using river water as raw water PAM (drinking water company). The concentration of organic matter and ammonia in the raw water PAM is increasing due to industrial and domestic waste pollution. Biofiltration combination with ultrafiltration process is use as one alternative to reduce concentration of organic matter, ammonia, iron, manganese and turbidity in raw water. In this treatment, biofilter reactor is use with plastic of Honeycomb tube type as media combined with ultrafiltration. Operational condition of treatment is variation of HRT (Hydraulyc Retention Time) between 1-4 hours and air supply between 0-30 I/min. The selected operational condition of treatment found at HRT of 2 hours and air supply of $20 \mathrm{l} / \mathrm{min}$, with removal efficiency of concentration of organic, ammonia, iron, manganese, and turbidity are $68 \%, 65 \%, 68 \%, 67 \%$, and $72 \%$ respectively.
\end{abstract}

Keywords: Biofiltration, ultrafiltration, honeycomb tube, removal efficiency, drinking water.

\section{PENDAHULUAN}

\subsection{Latar Belakang Masalah}

Pelayanan air bersih di Indonesia dalam skala yang besar masih terpusat di daerah perkotaan, dan dikelola oleh Perusahan Daerah Air Minum (PDAM) kota yang bersangkutan. Pelayanan 300 PDAM secara nasional belum mencukupi, yaitu dibawah $17 \%$ (2014). Daerah yang belum mendapatkan pelayanan air bersih dari PAM umumnya mereka menggunakan air tanah (sumur), air sungai, air hujan, air sumber (mata air) dan lainnya. Prosentase banyaknya rumah tangga dan sumber air minum yang digunakan di berbagai daerah di Indonesia sangat bervariasi tergantung dari kondisi geografisnya. Secara nasional adalah sebagai berikut: pengguna air PAM 16,8\%, air tanah (pompa) $11,7 \%$, air sumur (perigi) $49,6 \%$, mata air (air sumber) 12,7\%, air sungai 4,8\%, air hujan 2,5\% daur ulang dan lainnya $1,1 \%$. [1].

Kualitas air sungai yang dipakai sebagai sumber air baku perusahaan air minum (PAM) semakin menurun seiring dengan peningkatan jumlah penduduk, sebagai akibatnya biaya produksi semakin mahal dan pada kondisi tertentu menyebabkan PAM tidak dapat lagi memberikan pelayanan yang baik kepada masyarakat karena kualitas air olahan buruk. Masalahnya adalah dengan semakin buruknya kualitas air baku untuk air minum, maka disamping biaya produksinya membesar, hasil pengolahan berupa air bersih juga kurang baik bahkan tidak layak digunakan sebagai air minum. Salah satu masalah yang sering dijumpai pada air minum di dunia akhirakhir ini yakni timbulnya senyawa yang dinamakan Trihalomethanes atau disingkat THM, sebagai hasil samping dari proses disinfeksi dengan gas klor atau 
senyawa hipoklorit. Konsentrasi THM tertinggi di dalam air minum ditemukan setelah proses klorinasi berlangsung. THM terbentuk akibat reaksi antara klorine dengan senyawa natural seperti "humic substance" yang ada dalam air baku.[16]

THM adalah senyawa organik yang merupakan turunan dari methana $\left(\mathrm{CH}_{4}\right)$. Tiga buah atom Hidrogen $(\mathrm{H})$-nya diganti oleh atom halogen yaitu klor (Cl), Brom (Br), lodium (I). Beberapa senyawa THM yang sering dijumpai adalah dibromokloromethan $\left(\mathrm{CHBr}_{2} \mathrm{Cl}\right)$, bromodikholomethan $\left(\mathrm{CHBrCl}_{2}\right)$, kloroform $\left(\mathrm{CHCl}_{3}\right)$, dan bromoform $\left(\mathrm{CHBr}_{3}\right)$. Senyawa kloroform adalah merupakan salah satu senyawa THM yang paling umum dan sangat berpotensi sebagai penyebab kanker. Jumlah total ke empat senyawa tersebut sering disebut total trihalomethan (TTHM). Selain ke empat senyawa tersebut di atas masih ada beberapa senyawa trihalomenthan lainnya tetapi biasanya kurang stabil.[20]

Senyawa prekusor THM adalah Senyawasenyawa yang secara potensial dapat menyebabkan terjadinya THM. Salah satu precursor THM adalah senyawa humus (Humic and Fulvic Substances) yang secara alami terbentuk akibat proses pelapukan daun daun yang gugur atau sisa tumbuh-tumbuan yang telah mati oleh aktifitas mikroorganisme. Air limpasan hujan (Run Off) membawa senyawa humus dari daerah hutan atau pertanian, kemudian masuk ke aliran sungai pada. Air limbah baik domestik maupun industri juga mengandung zat organik yang besar, apabila tidak dikelola dengan baik akan masuk ke badan air sungai akan menjadi prekusor THM.[17]

Air sungai yang mengandung prekursor THM ini digunakan sebagai sumber air baku PAM. Senyawa precursor THM tersebut bereaksi dengan senyawa klor dalam proses desinfeksi sehingga terbentuklah senyawa THM dan senyawa halogen organik lainnya. Kandungan amoniak dalan air baku juga akan bereaksi dengan klor membentuk senyawa kloramine yang mempunyai daya disinfeksi lebih rendah, sebagai akibatnya konsumsi senyawa klor yang meningkat, sehingga terbentuknya THM juga semakin besar. [8]

Beberapa negara maju seperti Amerika, Canada, Eropa dan Jepang, konsentrasi total THMs dalam air minum maksimum yang dibolehkan yakni $0.1 \mathrm{mg} / \mathrm{l}$. Jepang menetapkan, jika konsentrasi COD (permanganate number) air permukaan yang dipakai sebagai air baku PAM lebih besar $12 \mathrm{mg} / \mathrm{l}$ atau warna lebih besar skala 20 atau lebih dibanding dengan air tanah, maka perusahaan air minum harus mulai melakukan pemantauan terhadap THM dalam air minum.[19]

Masalah THM di Indonesia sampai saat ini belum menjadi perhatian. Perusahaan air minum atau dalam hal ini PAM, hanya berkonsentrasi mengenai kwantitas dibanding dengan kualitas. Melihat kondisi air baku untuk PAM khususnya di kota-kota besar, misalnya Jakarta termasuk di dalamnya Tangerang dan Bekasi, Surabaya, Semarang serta kota-kota lainnya yang mengambil air bakunya dari sungai dengan kualitas yang sangat buruk, maka seharusnya masalah THM ini juga menjadi prioritas untuk dicari pemecahannya, karena THM ini adalah senyawa yang secara potensial dapat menyebabkan kanker (carcinogen).[19]

PDAM Tirta Kerta Raharja kabupaten Tangerang melakukan pemantauan kualitas air baku pada instalasi pangolahan air (IPA) wilayah Bojong Renged, Tangerang pada bulan September 2000. Kualitas air baku (sungai Cisadane) sudah tidak layak lagi digunakan sebagai sumber air baku PAM, karena salah satu parameter yaitu amoniak tidak memenuhi kriteria mutu air Golongan I.[12] Konsentrasi amoniak antara 0.06-1.09 mg/l, kondisi tersebut menjadi dua kali lipat bahkan lebih pada musim kemarau. Bulan agustus 2009 konsentrasi amoniak $\left(\mathrm{NH}_{4}-\mathrm{N}\right)$ mencapai $3.8 \mathrm{mg} / \mathrm{l}$ sehingga IPA Bojong Renged menghentikan proses pengolahan untuk sementara waktu, karena instalasi pengolahan yang ada sudah tidak mampu lagi mengolah dengan kondisi air baku seperti tersebut diatas.

PAM di Indonesia umumnya menggunakan senyawa klor (gas klor atau kalsium hipoklorit) untuk mereduksi mikroorganisma (desinfeksi). Selama proses desinfeksi gas klor juga bereaksi dengan senyawa organik, amoniak, logam besi dan mangan. Meningkatnya konsentrasi zat pencemar tersebut mengakibatkan kebutuhan klor semakin banyak, sebagai akibatnya muncul hasil samping dari proses klorinasi, yaitu terbentuknya senyawa trihalometan (THM) dan diikuti kenaikan konsentrasi senyawa halogen organik lainnya. Amoniak dalam air baku bereaksi dengan klor membentuk kloramin dengan daya desinfeksi lebih lemah, sehingga konsumsi khlor menjadi lebih besar, sebagai akibatnya biaya operasional meningkat.

Upaya PAM meningkatkan kualitas air olahan adalah dengan menerapkan pengolahan lanjutan (advanced treatment), yaitu menggunakan karbon aktif bubuk di bak pengendap akhir atau granular pada filter karbon aktif. Cara ini mampu meningkatkan kualitas air olahan, namun membutuhkan biaya yang tidak sedikit dan karbon aktif yang telah dipakai tidak dapat digunakan lagi (limbah padat). PAM sampai saat ini belum memungkinkan membuat instalasi baru yang menyesuaikan kualitas air baku, salah satu cara yang perlu dipertimbangkan saat ini adalah dengan melakukan pengolahan awal (pretreatment) menggunakan proses biologis (biological process) untuk meningkatkan kualitas air baku dengan penerapan proses biofiltrasi menggunakan media plastik tipe sarang tawon selanjutnya dilakukan 
pengolahan konvensional atau menggunakan ultrafiltrasi sebagai pengolahan akhir.

\subsection{Tujuan Penelitian}

Tujuan penelitian ini adalah mengkaji karakteristik dan membuat rekomendasi disain reaktor biofilter dengan media plastik tipe sarang tawon untuk dikombinasikan dengan ultrafiltrasi dalam menyediakan air minum yang memenuhi persyaratan sebagai air minum terhadap penyisihan konsentrasi senyawa organik, amoniak, besi, mangan dan kekeruhan dalam air baku PAM

\subsection{Ruang Lingkup}

Lingkup penelitian ini adalah: penerapan proses biofiltrasi dengan reaktor biofilter (bioreaktor) dan ultrafiltrasi, pembiakan mikroorganisma, pelaksanaan penelitian, analisa laboratorium dan perhitungan efisiensi penyisihan organik, amoniak, besi, mangan dan kekeruhan.

\section{TINJAUAN PUSTAKA}

\subsection{Mekanisme Penguraian Polutan di Biofilter}

Mikroorganisme di dalam reaktor biofilter, tumbuh melapisi keseluruhan permukaan media. Pada saat operasi, air yang mengadung polutan mengalir melalui celah media dan kontak langsung dengan lapisan massa mikroba (biofilm). Mikroorganisma yang ada pada biofilm akan mendegradasi senyawa organik yang ada di dalam air. Lapisan biofilm yang semakin tebal akan mengakibatkan berkurangnya difusi oksigen ke lapisan biofilm yang dibawahnya hal ini mengakibatkan terjadinya lingkungan anaerob pada lapisan biofilm bagian dalam. Mekanisme yang terjadi pada biofilter adalah: [11]

- Transportasi dan adsopsi zat organik dan nutrien dari fasa liquid ke fasa biofilm

- Transportasi mikroorganisma dari fasa cair (liquid) ke fasa biofilm

- Adsorpsi mikroorganisma yang terjadi dalam lapisan biofilm

- $\quad$ Reaksi metabolisma mikroorganisma yang terjadi dalam lapisan biofim, memungkinkan terjadinya mekanisme pertumbuhan, pemeliharaan, kematian dan lysis sel.

- Penempelan sel, yaitu pada saat lapisan biofilm mulai terbentuk dan terakumulasi secara kontinu dan gradual pada lapisan biofim.

- Mekanisme pelepasan biofilm (detachment biofilm) dan produk lainnya (by product).
Pertumbuhan mikrooorganisme akan terus berlangsung pada lapisan (slime) yang sudah terbentuk sehingga ketebalan slime semakin bertambah. Difusi makanan dan $\mathrm{O}_{2}$ berlangsung sampai ketebalam maksimum, sampai makanan dan $\mathrm{O}_{2}$ tidak mampu lagi mencapai permukaan padat atau bagian terjauh dari fase cair, sehingga menyebabkan lapisan biomassa terbagi menjadi dua bagian, yaitu lapisan aerob dan lapisan anaerob. Jika lapisan biofilm bertambah tebal maka daya lekat mikroorganisme terhadap media penyangga melemah dan tidak akan kuat menahan gaya berat lapisan biofilm, sehingga terjadi pengelupasan lapisan biomasa. Pengelupasan dapat juga terjadi karena pengikisan berlebihan cairan yang mengalir melalui biofilm. Koloni mikroorganisma yang baru akan terbentuk pada bagian yang terkelupas ini. Mekanisme proses yang terjadi pada sistem biofilter secara sederhana dapat ditunjukkan seperti pada Gambar 1.[6]

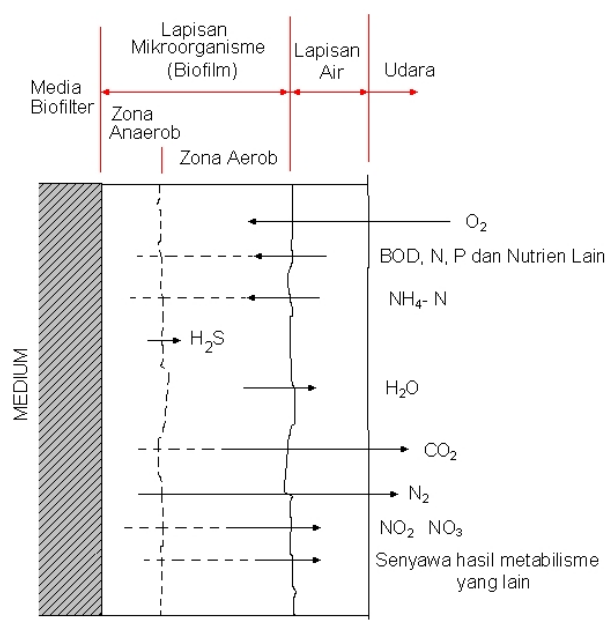

Gambar 1 : Mekanisme Proses Di Biofilm.

Efisiensi proses aerobik menurun dengan bertambahnya lapisan maksimum dan semakin tebalnya lapisan anaerob. Walaupun lapisan biomassa mempunyai ketebalan sampai $0,2 \mathrm{~mm}$ milimeter tetapi hanya lapisan luar setebal 0,05-0,15 $\mathrm{mm}$ yang merupakan lapisan aerob. Penghilangan substrat oleh lapisan mikroba akan bertambah secara linier dengan bertambahnya ketebalan film sampai dengan ketebalan maksimum, penghilangan tetap konstan dengan bertambahnya ketebalan lebih lanjut.[6]

\subsection{Proses Biologis untuk menghilangkan Senyawa organik dan amoniak}

Pengolahan air secara biologis merupakan suatau proses penguraian bahan-bahan pencemar, baik yang terlarut maupun yang tidak terlarut 
menjadi bentuk yang lain berupa gas atau padatan. Hasil dari transformasi tersebut dipengaruhi oleh kondisi lingkungan pada saat proses berlangsung yaitu kondisi aerobik dan anaerobik.[[2]

Proses pengolahan biologis secara aerobik merupakan suatu proses yang membutuhkan oksigen untuk menunjang berlangsungnya proses metabolisme biokimia oleh mikroorganisma dalam peruraian bahan-bahan organik menjadi bentuk yang lebih sederhana yaitu $\mathrm{CO}_{2}, \mathrm{H}_{2} \mathrm{O}$, senyawa-senyawa oksida seperti nitrat, sulfat, phosphat dan terbentuknya massa sel yang baru.[6]

Pada pengolahan secara biologis, pertumbuhan mikroorganisme dapat dilakukan secara melekat pada permukaan media penyangga (attached growth), yakni suatu proses pengolahan dimana senyawa-senyawa organik atau senyawasenyawa lainnya yang terdapat dalam air diuraikan oleh mikro-organisme yang melekat pada permukaan media penyangga menjadi senyawa yang lebih sederhana serta membentuk biomasa atau sel-sel baru. [22]

\subsection{Biofilter Unggun Tetap (Fixed bed Biofilter)}

Struktur reaktor biofilter menyerupai saringan (filter) yang terdiri dari susunan atau tumpukan bahan penyangga yang disebut dengan media penyangga dengan susunan secara teratur maupun acak di dalam suatu bejana. Fungsi media penyangga adalah sebagai tempat tumbuh dan berkembangnya mikroorganisma yang akan melapisi permukaan media membentuk lapisan massa yang tipis (biofilm) dan menguraikan bahan organik dan polutan lainnya yang ada dalam air. Media penyangga merupakan salah satu kunci keberhasilan proses biofilter. Efektifitas media tergantung pada :[2]

- Luas permukaan, yaitu semakin luas permukaan media maka semakin besar jumlah biomassa per unit volume.

- Volume rongga, yaitu semakin besar volume rongga atau ruang kosong maka semakin besar kontak antara substrat dalam air buangan dengan biomassa yang menempel

Faktor terpenting yang mempengaruhi pertumbuhan bakteri pada media penyangga adalah kecepatan aliran, bentuk dan jenis konfigurasi media. Media yang digunakan dapat berupa kerikil, batu pecah (split), media plastik (polivinil chlorida), dan partikel karbon aktif dan lainnya. Media yang sering digunakan pada proses biologis khususnya biofiter adalah media plastik yang terbuat dari PVC. Keuntungan penggunaan penggunaan media plastik ini antara lain : [2]
- Ringan, mudah dibentuk dan fleksibel dalam aplikasi

- Luas permukaan spesifik besar (luas permukaan per satuan volume) antara sebesar 85-226 $\mathrm{m}^{2} / \mathrm{m}^{3}$.

- Volume rongga lebih besar dibanding media lainnya (sampai 95\%) sehingga resiko kebuntuan kecil.

Di dalam reaktor biofilter ini, mikroorganisma menempel, tumbuh dan melapisi keseluruh permukaan media. Pada saat beroperasi air mengalir melalui celah-celah media dan berhubungan langsung dengan lapisan massa mikroba (biofilm). Mekanisme perpindahan massa yang terjadi pada permukaan suatu media dinyatakan sebagai berikut :

- Diffusi substansi air buangan dari cairan induk ke dalam masa mikroba yang melapisi media.

- Reaksi peruraian bahan organik maupun anorganik oleh mikroba.

- Diffusi produk peruraian ke luar menuju cairan induk limbah.

Permukaan media yang kontak dengan air yang mengandung polutan atau nutrisi yang terdapat dalam air buangan ini mengandung mikroorganisma yang membentuk lapisan aktif biologis. Disamping itu oksigen terlarut juga merupakan fator penting di dalam pembentukan lapisan film. Proses awal pertumbuhan mikroba dan pembentukan lapisan film pada media membutuhkan waktu antara 15 sampai 60 hari, tergantung dari komposisi air yang akan diolah dan dikenal dengan "proses pematangan". Pada awalnya tingkat efisiensi penyisihan polutan sangat rendah, selanjutnya mengalami peningkatan dengan terbentuknya lapisan film yang setabil.[9]

\subsection{Lapisan Biomassa}

Lapisan biomassa atau biofilm didefinisikan sebagai lapisan sel mikroba yang berkaitan dengan penguraian zat organik yang melekat pada suatu permukaan media. Proses penempelan, pembentukan koloni dan pertumbuhan lapisan sel mikroba dapat dilihat pada Gambar 2. [2]

Kecepatan pertumbuhan lapisan biofilm pada permukaan media akan bertambah seiring dengan perkembangbiakan dan adsorpsi yang terus berjalan sampai terjadi proses akumulasi lapisan biomassa dalam bentuk lapisan lendir (slime). Pertumbuhan mikroorganisma terus berlangsung pada slime yang sudah terbentuk sampai ketebalan slime mencapai maksimum. Difusi makanan dan oksigen juga terus berlangsung sehingga tercapai ketebalan maksimum dan pada kondisi ini difusi makanan maupun oksigen tidak mampu lagi mencapai permukaan padatan, akibatnya lapisan biomassa terbagi menjadi dua zona yaitu zona aerob dan zona anaerob. Pada kondisi ini mulai terjadi proses pengelupasan lapisan 
biomassa yang selanjutnya segera terbentuk koloni mikroorganisme baru, dengan demikian pembentukan biofilm terus berlangsung selama polutan atau nutrisi mencukupi. Proses pengelupasan ini juga disebabkan oleh pengikisan cairan yang berlebih yang mengalir melalui biofilm.[22]

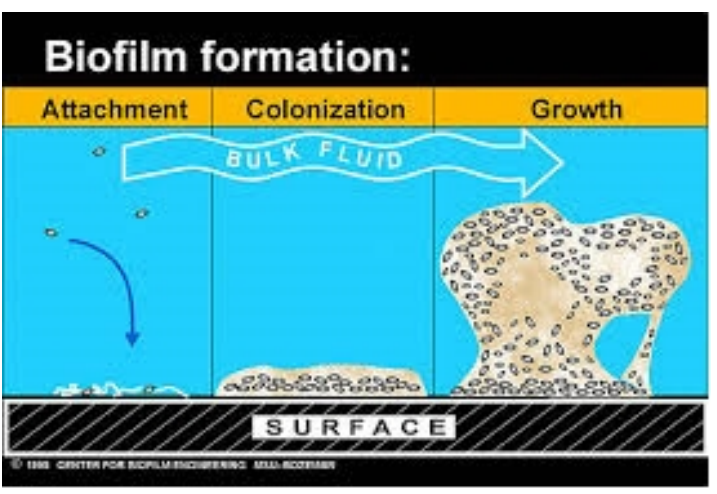

Gambar 2 : Proses Pembentukan Biofilm Pada Permukaan Media.

Efisiensi penghilangan amoniak pada proses biofilter oleh lapisan biomassa dapat mencapai maksimum bila lapisan tipis di sebelah luar lapisan biomassa telah mencapai ketebalan maksimum dalam kondisi aerobik.[21]

Mekanisme proses penguraian senyawa polutan yang terjadi pada lapisan biofilm secara sederhana dapat diilustrasikan seperti pada Gambar 1, sedangkan ilustrasi dari mekanisme proses penguraian amoniak di dalam biofilm dapat dilihat pada Gambar 4. Lapisan terluar media penyangga adalah lapisan tipis zona aerobik, senyawa amoniak dioksidasi dan diubah ke dalam bentuk nitrit. Sebagian senyawa nitrit ada yang diubah menjadi gas dinitrogen oksida $\left(\mathrm{N}_{2} \mathrm{O}\right)$ dan sebagian ada yang diubah menjadi nitrat. Proses yang terjadi tersebut dinamakan proses nitrifikasi.

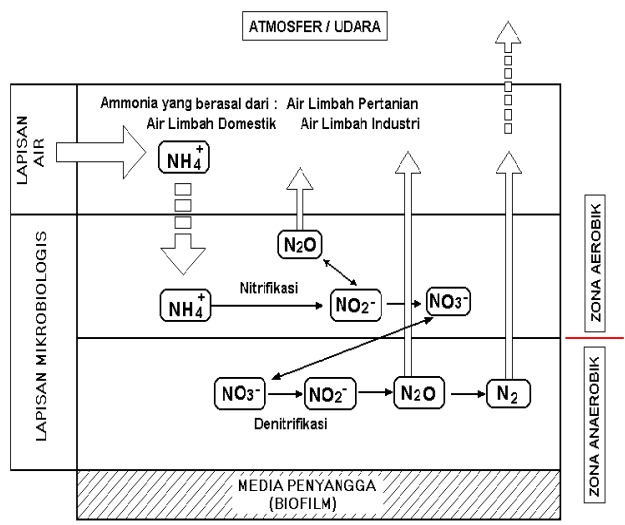

Gambar 3 : Ilustrasi Dari Mekanisme Proses Penguraian Amoniak Di Dalam Biofilm.
Semakin lama, lapisan biofilm yang tumbuh pada media penyangga tersebut semakin tebal sehingga menyebabkan oksigen tidak dapat masuk ke dalam lapisan biofilm yang mengakibatkan terbentuknya zona anaerobik. Pada zona anaerobik ini, senyawa nitrat yang terbentuk diubah ke dalam bentuk nitrit yang kemudian dilepaskan menjadi gas nitrogen $\left(\mathrm{N}_{2}\right)$. Proses demikian tersebut dinamakan proses denitrifikasi.[11]

\section{PENGOLAHAN AIR DENGAN PROSES BIOFILTRASI}

\subsection{Proses Pengolahan}

Proses biofiltrasi dilakukan di dalam reaktor biofilter yang dilengkapi dengan media. Reaktor biofilter dibuat dari bahan FRP dengan dimensi panjang $180 \mathrm{~cm}$, lebar $100 \mathrm{~cm}$ dan tinggi $160 \mathrm{~cm}$. Total volume reaktor biofilter 2880 liter, sedangkan volume kerja adalah 2520 liter. Media biofilter terbuat dari plastik tipe sarang tawon dengan ukuran modul $30 \times 30 \times 25 \mathrm{~cm}$, luas permukaan $226 \mathrm{~m}^{2} / \mathrm{m}^{3}$, porositas $98 \%$ dan total volume media yang digunakan adalah $0.855 \mathrm{~m}^{3}$. Spesifikasi reaktor biofilter secara lengkap dapat dilihat pada tabel 1 .

Reaktor biofilter dibagi menjadi 3 ruang, yaitu pengendap awal, media dilengkapi dengan penyangga dan pengendap akhir. Lubang masuk air baku (inlet) dan lubang air produk (outlet) terletak pada kedua sisi reaktor. Lumpur yang terendapkan dapat dikeluarkan melalui lubang ruang lumpur pada bagian bawah reaktor. Rancangan reaktor biofilter dapat dilihat pada Gambar 4 dan aplikasinya adalah seperti pada Gambar 5.

\subsection{Pembiakan Mikroorganisme (Seeding)}

Pembiakan (seeding) mikroorganisma dilakukan secara alami yaitu dengan cara mengalirkan air baku secara terus menerus ke dalam reaktor biofilter sampai terbentuknya lapisan biofilm yang melekat pada media biofilter dengan WTH 6 dan 8 jam. Proses pertumbuhan mikroorganisma ini didukung suplai udara 30 liter/menit secara terus menerus. Air baku kontak dengan mikroorganisma yang tersuspensi di dalam air maupun yang menempel pada permukaan media sehingga terjadi penguraian senyawa organik Pembiakan mikroba dilakukan dua tahap, tahap pertama dilakukan pengamatan secara visual tanpa analisa laboratorium, dimana pada tahap awal proses pengolahan ini belum berjalan dengan baik karena mikroorganisma belum tumbuh optimal. Setelah proses berjalan ke tahap dua yaitu mulai ada indikasi mikroba tumbuh yang ditandai dengan 
terbentuknya lapisan lendir (biofilm) pada permukaan media, mulai dilakukan analisa laboratorium. Lapisan biofilm ini mengandung mikroorganisma pengurai senyawa organik dalam air baku. Pertumbuhan mikroorganisme diamati dengan mengukur penyisihan senyawa organik di dalam bioreaktor setelah 7 hari proses sampai penyisihan senyawa organik stabil (steady state).

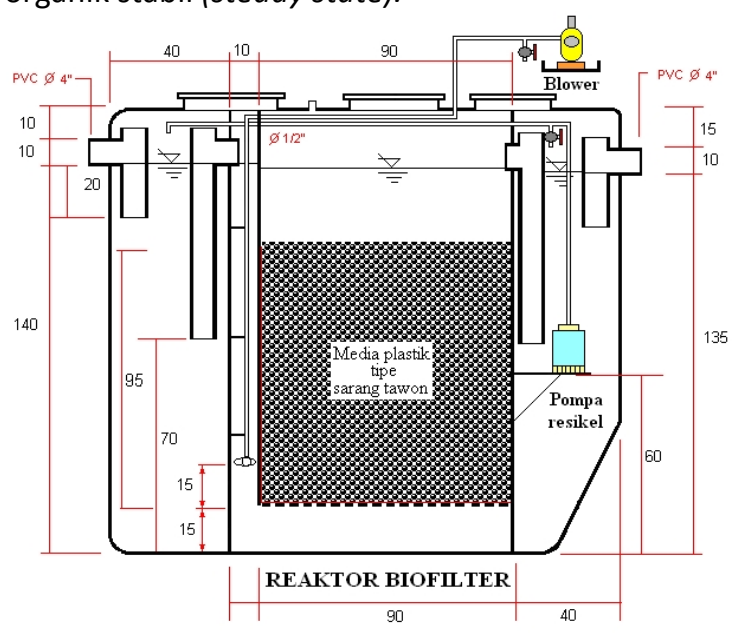

Gambar 4 : Rancangan Reaktor Biofilter.

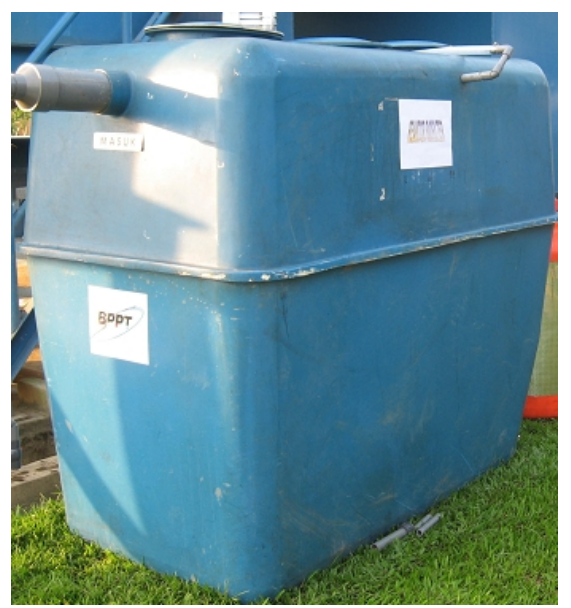

Gambar 5 : Reaktor Biofilter.

Efisiensi penyisihan organik pada awal pengoperasian masih rendah yaitu $29 \%$, hal ini disebabkan pertumbuhan mikroorganisme belum baik yang ditandai dengan biofilm yang terbentuk masih tipis. Minggu kedua efisiensi mulai meningkat menjadi 40\% dan minggu ketiga mencapai 69\%. Proses pengolahan pada akhir minggu ketiga telah mencapai kesetabilan, selanjutnya WTH diturunkan menjadi 6 jam. Perubahan WTH dari 8 jam menjadi 6 jam mengakibatkan laju alir meningkat dari 5.25 menjadi 7 liter/menit. Peningkatan laju alir air baku mengakibatkan waktu kontak air baku dengan lapisan biofilm menurun dan diikuti dengan kenaikan laju pembebanan senyawa organik, sehingga mengakibatkan efisiensi menurun. Setelah reaktor lima hari beroparasi dengan WTH 6 jam efisiensi sudah mulai menunjukkan kesetabilan. Fase ini disebut pematangan dan setelah mencapai kondisi stabil disimpulkan mikroorganisme pengurai telah tumbuh dan bekerja dengan baik.[9]

Efisiensi rata-rata penyisihan organik dengan WTH 6 jam sebesar $77 \%$ dan untuk mendapatkan WTH serta efisiensi penyisihan terbaik dilanjutkan dengan penurunan WTH menjadi 4 jam. Penyisihan organik pada saat seeding dapat dilihat pada Gambar6.

Tabel 1 : Spesifikasi Reaktor Biofilter.

\begin{tabular}{|c|c|c|c|}
\hline No & Uraian & Keterangan & Jumlah \\
\hline \multirow[t]{7}{*}{1} & Dimensi reaktor: & & 1 unit \\
\hline & Panjang & $180 \mathrm{Cm}$ & \\
\hline & Lebar & $100 \mathrm{~cm}$ & \\
\hline & Tinggi & $160 \mathrm{~cm}$ & \\
\hline & Volume reaktor & 2880 liter & \\
\hline & Volume efektif & 2520 liter & \\
\hline & Bahan & FRP & \\
\hline \multirow[t]{9}{*}{2} & Media biofilter : & & $0,855 \mathrm{~m}^{3}$ \\
\hline & Bahan / warna & Plastik/transparan & \\
\hline & Tipe & Sarang tawon & \\
\hline & Ukuran lubang & $(2 \times 2) \mathrm{cm}$ & \\
\hline & Ketebalan sheet & $0.5 \mathrm{~mm}$ & \\
\hline & Ukuran modul & $(30 \times 30 \times 25) \mathrm{cm}$ & \\
\hline & Luas permukaan & $\pm 226 \mathrm{~m}^{2} / \mathrm{m}^{3}$ & \\
\hline & Berat spesifik & $30-35 \mathrm{~kg} / \mathrm{m}^{3}$ & \\
\hline & Porositas media & $98 \%$ & \\
\hline \multirow[t]{3}{*}{3} & Flowmeter & & 2 unit \\
\hline & Kapasitas & 0-26 liter/menit & \\
\hline & Diameter in/out & $1 / 2$ inch & \\
\hline \multirow[t]{4}{*}{4} & Blower udara & & 2 unit \\
\hline & Tipe & Hiblow 30, & \\
\hline & daya & $60 \mathrm{~W} / 220 \mathrm{~V}$ & \\
\hline & Kapasitas & 30 liter/menit & \\
\hline \multirow[t]{4}{*}{5} & Difuser (diffucer) & & 4 unit \\
\hline & Tipe & Gelembung (Bubble) & \\
\hline & diameter & $7.5 \mathrm{~cm}$ & \\
\hline & Kapasitas & 20 liter/menit & \\
\hline \multirow[t]{4}{*}{6} & Pompa sirkulasi & & 1 unit \\
\hline & Tipe & Celup (submercible) & \\
\hline & Kapasitas & 2-15 liter/menit & \\
\hline & Daya & $100 \mathrm{~W} ; 220 \mathrm{~V}$ & \\
\hline \multirow[t]{2}{*}{7} & Perpipaan & Instalasi $1 / 2$ " $-4 "$ & 1 paket \\
\hline & kelistrikan & $110 \mathrm{~W}, 220 \mathrm{~V}$ & \\
\hline
\end{tabular}

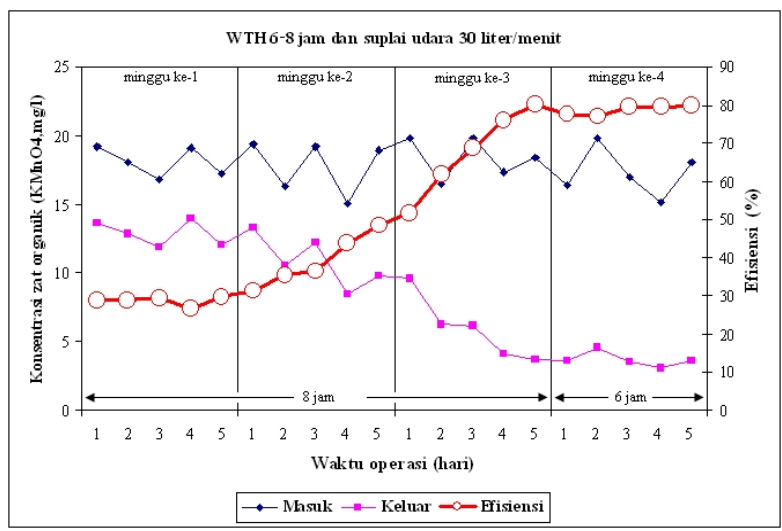

Gambar 6 :Penyisihan Organik $\left(\mathrm{Kmno}_{4}\right)$ Selama Proses Seeding. 


\subsection{Penyisihan Amoniak}

Penyisihan organik lebih mudah dibandingkan dengan penyisihan amoniak sehingga pengamatan penyisihan amoniak di dalam penelitian ini menjadi dasar penentuan waktu tinggal hidrolis dan jumlah suplai udara.

\subsubsection{Pengaruh WTH Terhadap Penyisihan Amoniak $\left(\mathrm{NH}_{4}-\mathrm{N}\right)$}

Penurunan efisiensi penyisihan senyawa amoniak sebanding dengan penurunan WTH. Penurunan konsentrasi amoniak dalam biofiter menunjukkan terjadinya proses penguraian amoniak pada saat nitrifikasi. Penguraian amoniak pada saat nitrifikasi dilakukan oleh mikroorganisma autotrof maupun heterotrof untuk mensintesa sel. Seperti ditunjukkan pada Gambar 7, efisiensi penyisihan amoniak pada WTH 1-4 jam sebesar $44 \%, 65 \%, 68 \%$, dan $71 \%$.

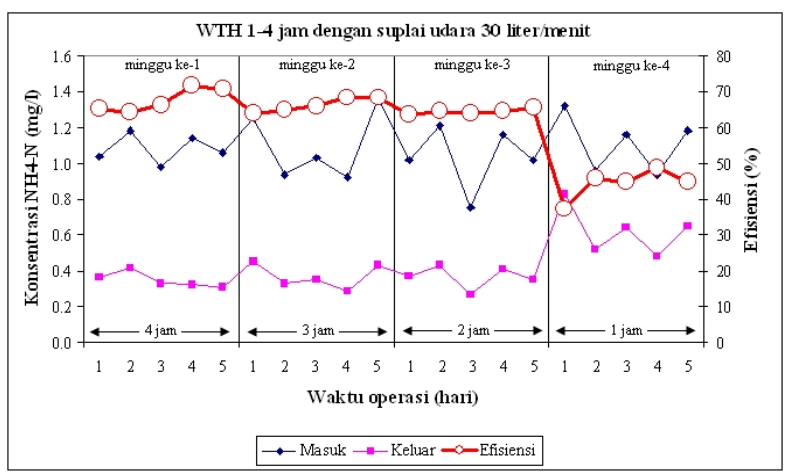

Gambar 7 : Penyisihan Amoniak (WTH 1-4 Jam).

Gambar di atas memperlihatkan efisiensi penyisihan amoniak menurun seiring dengan berkurangnya WTH di dalam reaktor, hal ini disebabkan berkurangnya waktu kontak antara air baku dengan lapisan biomassa yang tumbuh di media, akibatnya amoniak yang terurai semakin kecil. Efisiensi penyisihan rata-rata tertinggi didapat pada pengkondisian WTH 4 jam yaitu sebesar $71 \%$ dan terendah saat WTH 1 jam sebesar 44\%. Efisiensi penyisihan amoniak pada WTH antara 2 sampai 4 jam masih tergolong tinggi, hal ini disebabkan waktu kontak antara mikroba dengan air baku dan oksigen terlarut masih mencukupi untuk kebutuhan mikroba melakukan sintesa. Pada saat terjadinya penyisihan konsentrasi amoniak di dalam air, terjadi peningkatan konsentrasi nitrat. Perubahan konsentrasi nitrat sebelum dan sesudah pengolahan ditujukkan seperti pada gambar 8 .

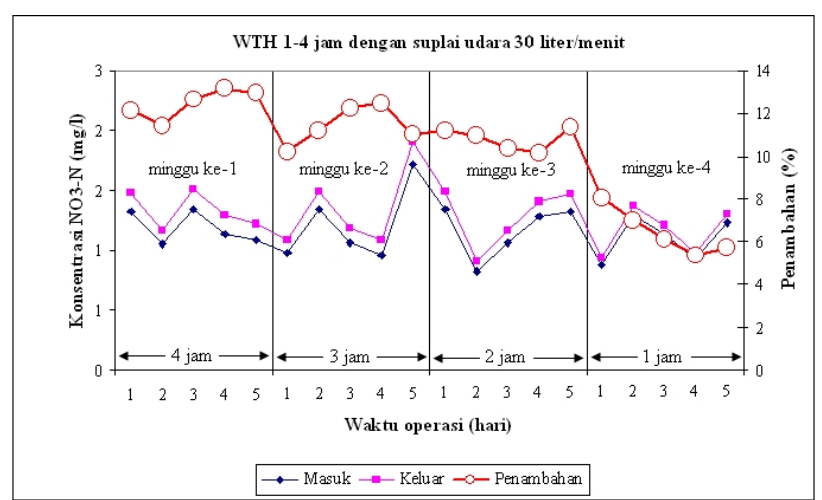

Gambar 8 : Peningkatan Konsentrasi Nitrat ( $\left.\mathrm{NO}_{3}-\mathrm{N}\right)$ Pada WTH 1-4 Jam.

Peningkatan konsentrasi nitrat $\left(\mathrm{NO}_{3}-\mathrm{N}\right)$ dapat disebabkan adanya suplai oksigen ke dalam reaktor biofilter, dengan reaksi seperti di bawah ini:[2]

$\begin{array}{lll}\mathrm{NO}_{2}^{-}+1 / 2 \mathrm{O}_{2} & \rightarrow & \mathrm{NO}_{3}^{--} \\ \mathrm{NH}_{4}^{+}+2 \mathrm{O}_{2} & \rightarrow & \mathrm{NO}_{3}^{--}+2 \mathrm{H}^{+}+\mathrm{H}_{2} \mathrm{O}\end{array}$

Senyawa nitrit merupakan senyawa peralihan di dalam siklus biologi. Senyawa ini dihasilkan dari suatu proses oksidasi $\mathrm{NH}_{4}-\mathrm{N}$, tetapi sifatnya tidak stabil karena pada kondisi aerobik selama nitrit terbentuk, selanjutnya dengan cepat nitrit dioksidasi menjadi nitrat oleh bakteri nitrobacter, oleh karena itu senyawa nitrit ditemukan dalam jumlah yang kecil. Perubahan konsentrasi nitrit sebelum dan sesudah pengolahan ditujukkan seperti pada gambar 10 .

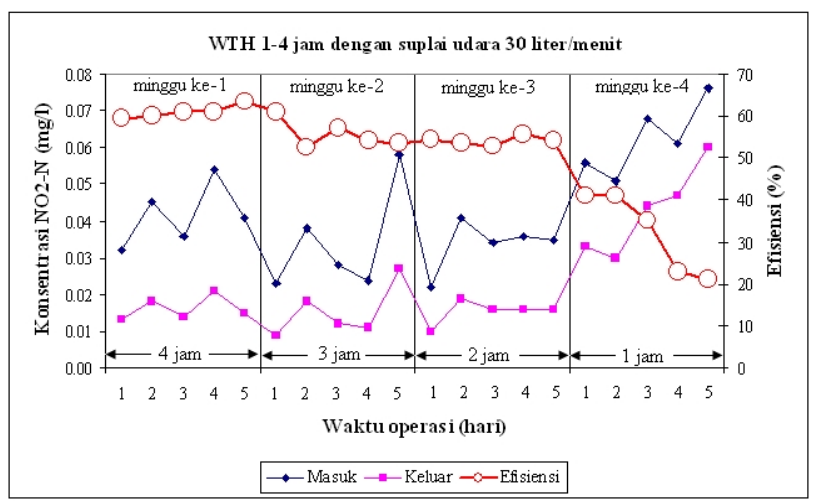

Gambar 9 : Penyisihan Nitrit $\left(\mathrm{NO}_{2}-\mathrm{N}\right)$ Pada WTH 1-4 Jam.

\subsubsection{Laju Pembebanan Amoniak $\left(\mathrm{NH}_{4}-\mathrm{N}\right)$}

Terjadinya penurunan efisiensi amoniak adalah akibat dari penurunan WTH, sehingga laju pembebanan amoniak semakin besar. Penurunan WTH diikuti oleh penurunan efisiensi penyisihan, peningkatan debit air baku dan laju pembebanan amoniak. 
Penurunan WTH mengakibatkan debit air baku meningkat sehingga beban hidrolis juga meningkat, sebagai akibatnya efisiensi penyisihan amoniak mengalami penurunan. Laju pembebanan amoniak dalam reaktor biofilter bermedia plastik tipe sarang tawon dengan luas permukaan $226 \mathrm{~m}^{2} / \mathrm{m}^{3}$ pada WTH 1-4 jam adalah 0.4, 0.2, 0.1, dan $0.1 \mathrm{~g} / \mathrm{m}^{2}$ media.hari, sedangkan efisiensi penyisihan adalah 47\%, 65\%, $68 \%$, dan $71 \%$.

Gambar 10 berikut ini menunjukkan hubungan linear antara laju pembebanan dengan efisiensi penyisihan amoniak, dengan persamaan sebagai berikut:

$\mathrm{y}_{\mathrm{a}}=-91.19 \mathrm{x}_{\mathrm{a}}+77.12$

dengan $R^{2}=0.92$

dimana,

$\mathrm{y}_{\mathrm{a}}=$ Efisiensi penyisihan amoniak, $\mathrm{NH}_{4}-\mathrm{N}(\%)$

$\mathrm{x}_{\mathrm{a}}=$ Laju pembebanan amoniak, $\mathrm{NH}_{4}-\mathrm{N}\left(\mathrm{g} / \mathrm{m}^{2}\right.$ media/hari)

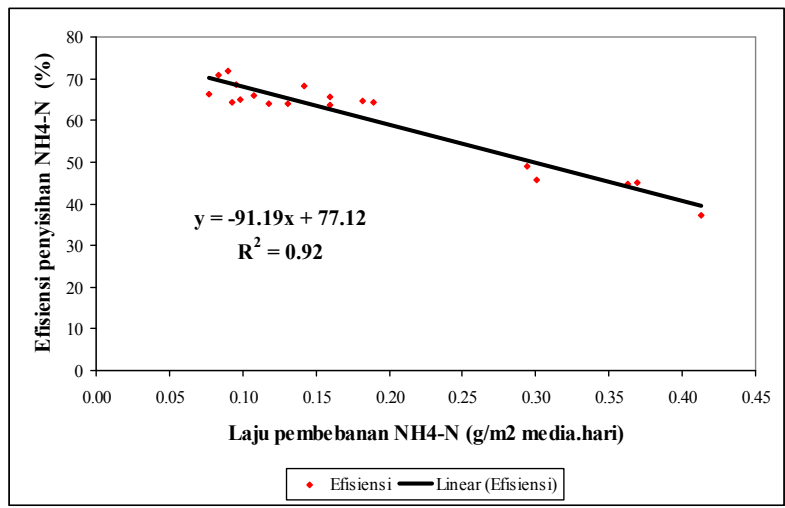

Gambar 10 : Laju Pembebanan Dengan Efisiensi Penyisihan Amoniak.

Laju Pembebanan amoniak diikuti dengan penurunan efisiensi amoniak.

\subsubsection{Penentuan WTH Tepilih}

WTH terpilih ditentukan melalui seleksi nilai efisiensi penyisihan senyawa amoniak, dengan mempertimbangkan penyisihan amoniak lebih sulit dibandingkan dengan parameter lainnnya sehingga dapat mewakili data untuk keperluan teknis perencanaan, kelayakan dan aplikasi teknologi biofilter. Waktu tinggal hidrolis yang dipilih adalah WTH tersingkat namun efisiensi penyisihan optimal atau tertinggi dan setabil. Efisiensi penyisihan amoniak rata-rata pada WTH 4 jam sebesar $71 \%$. Efisiensi penyisihan rata-rata amoniak dapat dilihat pada Tabel 3.
Tabel 3 : Rata-Rata Efisiensi Penyisihan Amoniak Pada WTH 1-4 Jam.

\begin{tabular}{cc}
\hline WTH (jam) & $\begin{array}{c}\text { Rata-rata efisiensi penyisihan } \\
\text { Amoniak }\left[\mathrm{NH}_{4}-\mathrm{N}\right](\%)\end{array}$ \\
\hline 1 & 44 \\
2 & 65 \\
3 & 68 \\
4 & 71 \\
\hline
\end{tabular}

Beberapa hal penting yang perlu diperhatikan di dalam teknis perencanaan dan aplikasi reaktor biofilter, antara lain:

- Waktu tinggal hidrolis dalam reaktor singkat

- Efisiensi penyisihan polutan tinggi

- Ukuran lahan yang dipakai kecil

- Bentuk rancangan fleksibel

- Biaya investasi dan operasional rendah

- Air hasil olahan memenuhi kriteria mutu air Golongan I.[12]

Ukuran, bobot reaktor, efisiensi penyisihan dan kebutuhan energi merupakan faktor penting dalam perencanaan pembangunan instalasi pengolahan air. Ukuran reaktor menjadi acuan dalam penyediaan lahan sedangkan bobot reaktor menjadi pertimbangan konstruksi, dimana semakin kecil WTH, ukuran reaktor semakin hemat dalam penggunaan lahan dan dengan bobot reaktor yang lebih kecil memerlukan konstruksi yang lebih ringan. Reaktor dengan efisiensi tinggi mempunyai kemampuan yang lebih besar dalam mengolah air sehingga lebih efisien dalam pemakaian energi untuk peralatan pendukung seperti pompa dan blower. Kualitas air hasil pengolahan juga merupakan faktor yang penting di dalam penentuan pemilihan waktu tinggal hidrolis. Kualitas air baku dan hasil pengolahan proses biofiltrasi pada WTH 1-4 jam dapat dilihat pada Tabel 4.

Tabel 4 : Kualitas Air Baku Dan Hasil Pengolahan Pada WTH 1-4 Jam.

\begin{tabular}{ccccc}
\hline \multirow{2}{*}{$\begin{array}{c}\text { WTH } \\
\text { (jam) }\end{array}$} & \multicolumn{3}{c}{ Konsentrasi rata-rata amoniak (mg/liter) } \\
\cline { 2 - 5 } Masuk & $\mathrm{X}$ & 0.60 & $\mathrm{~V}$ \\
2 & 1.11 & $\mathrm{X}$ & 0.39 & $\mathrm{~V}$ \\
3 & 1.03 & $\mathrm{X}$ & 0.37 & $\mathrm{~V}$ \\
4 & 1.10 & $\mathrm{X}$ & 0.33 & $\mathrm{~V}$ \\
\hline
\end{tabular}

Keterangan:

$\mathrm{x}=$ Tidak memenuhi mutu air golongan I PPRI No. 82/2001 (0,5 mg/l) $\mathrm{v}=$ Memenuhi kriteria mutu air golongan I PPRI No. 82/2001 $(0,5 \mathrm{mg} / \mathrm{l})$

Waktu tinggal hidrolis 2 jam diambil sebagai WTH terpilih, dimana WTH 2 jam adalah WTH terpendek dengan efisiensi penyisihan amoniak relatif tinggi. Pertimbangan lain adalah air hasil pengolahan 
memenuhi kriteria mutu golongan I, yaitu air yang dapat digunakan sebagai air baku air minum.[11]

\subsubsection{Pengaruh Suplai Udara Terhadap Penyisihan Amoniak $\left(\mathrm{NH}_{4}-\mathrm{N}\right)$}

Efisiensi penyisihan amoniak dengan WTH 2 jam dan variasi suplai udara 0-30 liter/menit ditunjukkan pada Gambar 11. Penurunan konsentrasi amoniak diikuti dengan peningkatan konsentrasi nitrat, hal ini menunjukkan bahwa di dalam reaktor biofilter telah terjadi proses nitrifikasi. Mikroba yang terlibat dalam proses ini adalah bakteri autotrof yang berperan dalam proses nitrifikasi, sedangkan bakteri heterotrof berperan dalam penguraian beban organik. Walaupun bakteri autotrof berperan dalam proses nitrifikasi, proses ini dapat juga terjadi dengan adanya bakteri heterotrof.

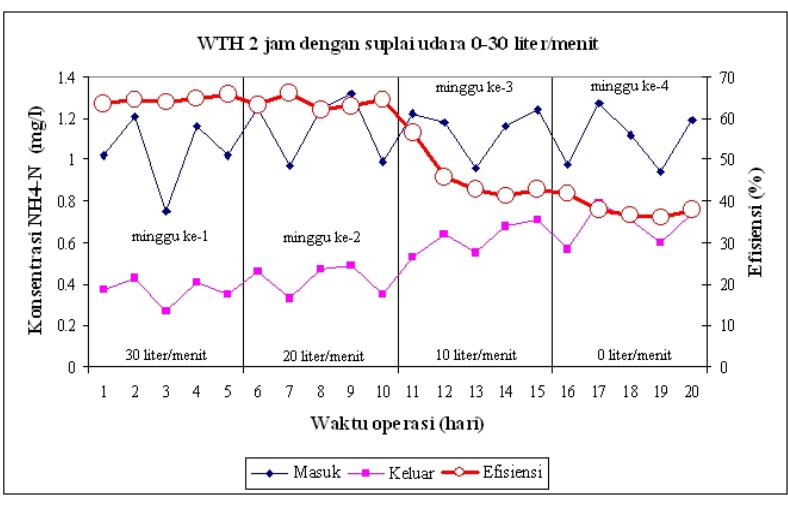

Gambar 11 : Penyisihan Amoniak Pada WTH 2 Jam Dan Suplai Udara 0-30 Liter/Menit.

Pengolahan dengan pengkondisian WTH dari 2 jam dan suplai udara 0-30 liter/menit menghasilkan efisiensi penyisihan rata-rata berturut-turut sebesar $37 \%, 43 \%, 65 \%$ dan 65\%. Penurunan konsentrasi amoniak pada air olahan menunjukkan terjadinya proses penguraian amoniak pada saat nitrifikasi di dalam reaktor biofilter. Penguraian amoniak pada proses nitrifikasi dilakukan oleh mikroorganisme autotrof maupum heterotrof dalam mensintesa sel.

Identifikasi mikroorganisma yang terdapat dalam biofilm, terdapat bakteri nitrosomonas dan nitrobacter (Laboratorium FKH IPB, 2010). Nitrifikasi merupakan proses pengubahan $\mathrm{NH}_{4}-\mathrm{N}$ menjadi $\mathrm{NO}_{2}-\mathrm{N}$ yang kemudian menjadi $\mathrm{NO}_{3}-\mathrm{N}$ yang dilakukan oleh bakteri autotropik dan heterotropik. Pengubahan $\mathrm{NH}_{4}-\mathrm{N}$ menjadi $\mathrm{NO}_{2}-\mathrm{N}$ dilakukan oleh bakteri nitrosomonas dan selanjutnya $\mathrm{NO}_{2}-\mathrm{N}$ yang terbentuk diubah menjadi $\mathrm{NO}_{3}-\mathrm{N}$ oleh bakteri nitrobacter. Kedua jenis bakteri diatas berlangsung dalam keadaan aerob sehingga memerlukan konsentrasi oksigen yang cukup untuk sumber energi dalam menunjang proses metabolisme, dan juga proses nitrifikasi merupakan suatu proses aerob sehingga keberadaan oksigen sangat penting dalam proses ini. Konsentrasi oksigen terlarut yang diperlukan agar proses nitrifikasi dapat berjalan dengan baik yaitu jika DO minimumnya $>1 \mathrm{mg} / \mathrm{l}$ tetapi bila konsentrasi DO dibawah $1 \mathrm{mg} / \mathrm{l}$ maka proses nitrifikasi menjadi lambat.

Fungsi suplai udara pada reaktor biofilter adalah mensuplai oksigen untuk mendukung mikroorganisma melakukan penguraian polutan dalam air baku dan digunakan untuk menjaga kestabilan biofilm dari gangguan material yang menghalangi lapisan biomasa dan merontokkan biofilm yang telah mati. Perubahan suplai udara dari 20 menjadi 10 dan 0 liter/menit mengakibatkan efisiensi penyisihan senyawa organik turun dengan efisiensi rata-rata penyisihan $43 \%$ dan $37 \%$. DO yang terukur pada titik masuk sekitar $5.5 \mathrm{mg} / \mathrm{l}$ dan pada titik keluar sekitar $3 \mathrm{mg} / \mathrm{l}$. Syarat DO yang diperlukan dalam proses biofiltrasi mencukupi mikroorganisma untuk melakukan penguraian senyawa amoniak, walaupun mendekati syarat minimal. Suhu operasi reaktor biofilter antara 28.2-28.7 dan pH antara 7.17.5 adalah kondisi yang baik untuk mikroorganisma melakukan penguraian.

Inhibitor maupun toksik tidak teridentifikasi di dalam sistem, faktor penghambat yang menghalangi lapisan biofilm kontak dengan air baku kemungkinan bisa terjadi dari pengendapan tanah, lempung dan pasir halus yang menutupi sebagian lapisan biomasa. Lempung dan tanah halus yang tersuspensi di dalam air baku. Penurunan efisiensi penyisihan senyawa amoniak di dalam reaktor biofilter pada variasi suplai udara 0-10 liter/menit dapat dikatakan akibat tertutupnya biofilm oleh tanah halus dan lempung sehingga luas kontak antara biofilm dengan air baku berkurang dan mikrooganisma tidak mendapatkan suplai oksigen dan makanan yang mencukupi.

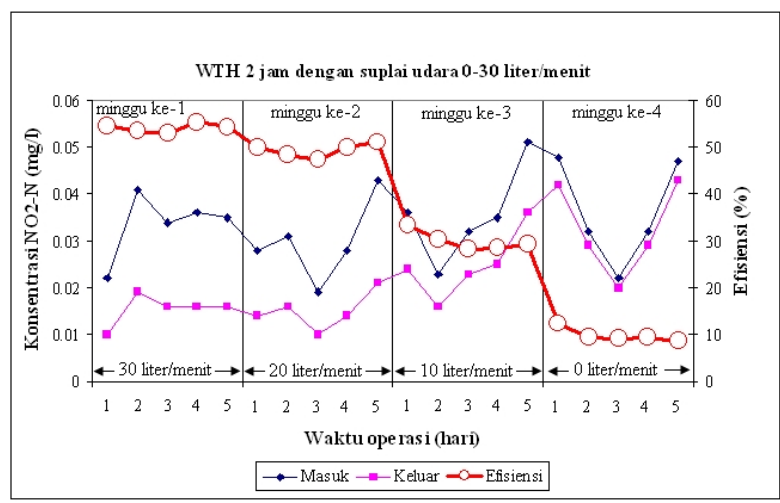

Gambar 12 : Penyisihan $\mathrm{NO}_{2}-\mathrm{N}$ Pada WTH 2 Jam Dan Suplai Udara 0-30 Liter/Menit.

Penurunan konsentrasi amoniak $\left(\mathrm{NH}_{4}-\mathrm{N}\right)$ diikuti dengan penurunan nitrit $\left(\mathrm{NO}_{2}-\mathrm{N}\right)$ dan peningkatan konsentrasi nitrat $\left(\mathrm{NO}_{3}-\mathrm{N}\right)$. Perubahan 
konsentrasi $\left(\mathrm{NO}_{2}-\mathrm{N}\right) \quad\left(\mathrm{NO}_{3}-\mathrm{N}\right)$ pada saat penurunan konsentrai $\mathrm{NH}_{4}-\mathrm{N}$ dapat dilihat pada Gambar $12 \mathrm{di}$ atas dan Gambar 13. Senyawa nitrit merupakan senyawa peralihan dalam siklus biologi. Senyawa ini dihasilkan dari proses oksidasi $\mathrm{NH}_{4}-\mathrm{N}$, tetapi sifatnya tidak stabil karena pada kondisi aerobik selama nitrit terbentuk, dengan cepat nitrit dioksidasi menjadi nitrat oleh bakteri nitrobacter, oleh karena itu senyawa nitrit ditemukan dalam jumlah yang kecil. Peningkatan konsentrasi $\mathrm{NO}_{3}-\mathrm{N}$ dapat disebabkan adanya oksigen yang dialiri secara terus menerus ke dalam reaktor, sehingga dapat menyebabkan pembentukan nitrat, seperti pada persamaan 1 dan 2[2].

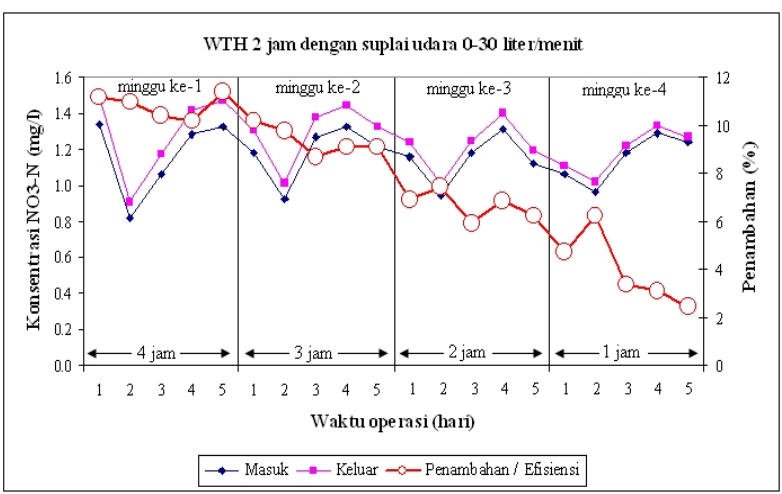

Gambar 13 : Peningkatan Konsentrasi $\mathrm{NO}_{3}-\mathrm{N}$ Pada WTH 2 Jam Dan Suplai Udara 0-30 Liter/Menit.

$\mathrm{pH}$ optimum untuk aktivitas bakteri nitrosomonas dan nitrobacter agar dapat berjalan dengan optimal yaitu antara 7,5-8,5. Kondisi operasi reaktor biofilter dengan $\mathrm{pH}$ antara 7,0 - 7,5 menyebabkan peran bakteri nitrosomonas dalam proses nitrifikasi belum berjalan secara optimal, begitu pula dengan bakteri nitrobacter yang mengubah nitrit menjadi nitrat. Berdasarkan pernyataan tersebut efisiensi penyisihan yang rendah pada WTH 2 jam dan suplai udara 0-10 liter/menit, selain dari gangguan tertutupnya lapisan biofilm oleh tanah halus, dapat juga disebabkan bakteri nitrosomonas dan nitrobacter tidak bekerja maksimal [15].

Bahan organik merupakan salah satu faktor yang dapat mempengaruhi banyak atau sedikitnya konsentrasi amonium yang terjadi dalam proses nitrifikasi. Pada air buangan, $60 \%$ nitrogen mengandung bahan organik, $40 \%$ nitrogen berada dalam bentuk amoniak, dan $<1 \%$ berada dalam bentuk nitrit dan nitrat. Bakteri heterotrof menggunakan substrat organik sebagai sumber energinya sedangkan bakteri autotrof menggunakan senyawa $\mathrm{CO}_{2}$ dan $\mathrm{HCO}_{3}{ }^{-}$sebagai sumber energi yang diperoleh dari hasil oksidasi bakteri heterotrof, maka dapat dikatakan bahwa efisiensi penyisihan pada proses nitrifikasi sejalan dengan poses penyisihan organik.

\subsubsection{Penentuan Suplai Udara Terpilih}

Seperti telah dijelaskan di atas beberapa hal penting yang perlu diperhatikan di dalam teknis perencanaan dan kelayakan aplikasi reaktor biofilter, antara lain:

- Waktu tinggal hidrolis dalam reaktor singkat

- Efisiensi penyisihan polutan tinggi

- Ukuran lahan yang dipakai kecil

- Bentuk rancangan fleksibel

- Biaya investasi dan operasional rendah

- Air hasil olahan memenuhi kriteria mutu Golongan I.[12]

Luas lahan yang dibutuhkan untuk instalasi, ukuran dan bobot reaktor, serta waktu tinggal, efisiensi penyisihan dan kebutuhan energi merupakan faktor penting dalam pembangunan fisik instalasi pengolahan air. Ukuran reaktor menjadi penentu dalam luas lahan yang dibutuhkan, sedangkan bobot reaktor menjadi pertimbangan kemudahan dan efisiensi konstruksi. WTH mempengaruhi dimensi reaktor, semaki kecil WTH dimensi reaktor semakin kecil. Dimensi reaktor biofilter yang ringkas hemat dalam menggunakan lahan, bobot lebih ringan dan konstruksi lebih murah. Reaktor dengan efisiensi tinggi mempunyai kemampuan yang lebih besar dalam mengolah air sehingga lebih efisien dalam pemakaian energi untuk peralatan pendukung seperti pompa, blower dan peralatan pendukung lainnya. Kualitas air hasil pengolahan juga merupakan faktor yang penting di dalam pertimbangan pemilihan jumlah suplai udara. Kualitas air baku dan hasil pengolahan dari proses biofiltrasi pada WTH 2 jam dan suplai udara 0-30 liter/menit dapat dilihat pada Tabel 5. Analisa laboratorium hasil pengolahan secara lengkap dapat dilihat pada Tabel 6 .

Tabel 5 : Kualitas Air Baku Dan Hasil Pengolahan Pada WTH 2 Jam Dan Suplai Udara 0-30 Liter/Menit.

\begin{tabular}{ccccc}
\hline WTH (jam) & \multicolumn{3}{c}{$\begin{array}{c}\text { Konsentrasi rata-rata amoniak } \\
\text { (mg/liter) }\end{array}$} \\
\cline { 2 - 5 } & \multicolumn{3}{c}{ Masuk } & \multicolumn{2}{c}{ Keluar } \\
\hline 0 & 1.10 & $\mathrm{X}$ & 0.68 & $\mathrm{X}$ \\
10 & 1.15 & $\mathrm{X}$ & 0.62 & $\mathrm{X}$ \\
20 & 1.15 & $\mathrm{X}$ & 0.42 & $\mathrm{~V}$ \\
30 & 1.03 & $\mathrm{X}$ & 0.37 & $\mathrm{~V}$ \\
\hline
\end{tabular}

Keterangan:

$\mathrm{x}=$ Tidak memenuhi mutu air golongan I PPRI No. 82/2001 ( 0,5 mg/l)

$\mathrm{v}=$ Memenuhi mutu air golongan I PPRI No. 82/2001

$(0,5 \mathrm{mg} / \mathrm{l})$ 
WTH 2 jam dan suplai udara 20 liter/menit diambil sebagai suplai udara terpilih, dimana pada suplai udara 20 liter/menit adalah merupakan suplai udara terbaik dengan efisiensi penyisihan tergolong tinggi untuk mereduksi amoniak dan air hasil pengolahan memenuhi kriteria mutu golongan I.[12]

\subsection{Penghilangan Senyawa Organik}

\subsubsection{Efisiensi Penyisihan Organik dengan WTH 2 jam dan Suplai Udara 20 liter/menit}

Pengamatan perubahan konsentrasi zat organik sebelum dan sesudah pengolahan serta efisiensi penyisihan zat organik di dalam reaktor biofilter pada WTH 2 jam dengan suplai udara 0-30 liter/menit secara lengkap ditunjukkan seperti ditunjukkan pada Gambar 12.

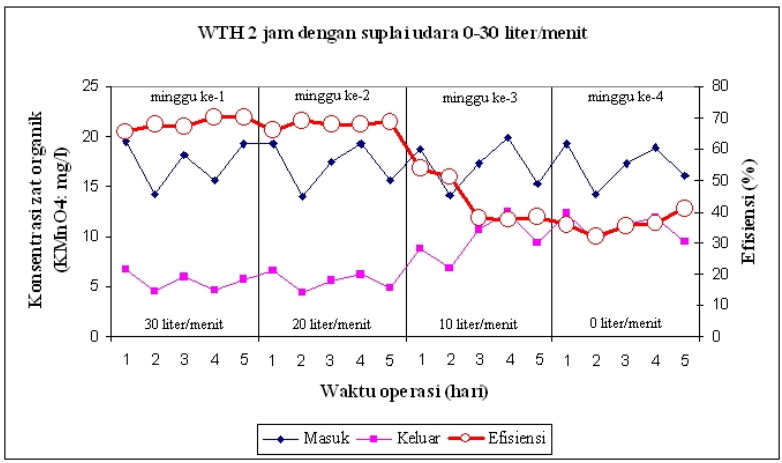

Gambar 12 : Penyisihan Organik Dengan WTH 2 Jam Dan Suplai Udara 0-30 Liter/Menit.

Pada pengolahan dengan WTH 2 jam dengan suplai udara 0 sampai 30 liter/menit berturut-turut sebesar 38\%, 38\%, 68\% dan 70\%. Dari hasil penelitian tersebut terlihat bahwa setelah suplai udara dirubah dari 30 menjadi 20 liter/menit terjadi penurunan efisiensi penyisihan senyawa organik dari $70 \%$ menjadi $68 \%$ dan penurunan suplai udara dari 20 menjadi 0 liter/menit terjadi penurunan efisiensi penyisihan senyawa organik dari $68 \%$ menjadi $38 \%$.

Efisiensi penyisihan senyawa organik pada WTH 2 jam dan suplai udara 20 liter/menit masih tinggi, yaitu sekitar 68\%, hal ini disebabkan waktu kontak kontak mencukupi, tidak ada senyawa penggangu (inhibitor), jenis dan jumlah mikroorganisme pengurai mencukupi untuk melakukan penguraian. Adanya oksigen terlarut yang mencukupi ( \pm 4 ppm) menyebabkan proses oksidasi aerob di dalam reaktor biofilter dapat berlangsung dengan baik, bahan-bahan organik akan dirubah menjadi $\mathrm{NH}_{3}, \mathrm{CO}_{2}, \mathrm{H}_{2} \mathrm{O}$, produk - produk akhir yang relatif stabil dan energi serta sisanya akan disintesis menjadi mikroba baru. Secara umum mekanisme penguraian organik dapat dilihat pada persamaan di bawah ini:[2]

Oksidasi

$\mathrm{COHNS}+\mathrm{O}_{2}+$ bakteri $\longrightarrow \mathrm{CO}_{2}+\mathrm{NH}_{3}+$ produk + energi akhir (Materi organik)

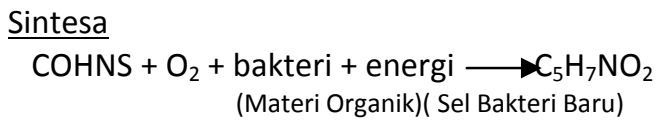

Respirasi

$$
\mathrm{C}_{5} \mathrm{H}_{7} \mathrm{NO}_{2}+5 \mathrm{O}_{2} \longrightarrow \underset{\text { Energi(6) }}{5 \mathrm{CO}_{2}+\mathrm{NH}_{3}+2 \mathrm{H}_{2} \mathrm{O}+}
$$

Pada proses suplai udara diubah dari 20 menjadi 10 dan 0 liter/menit efisiensi penyisihan senyawa organik semakin turun dengan efisiensi ratarata penyisihan $38 \%$. Oksigen terlarut yang terukur pada titik masuk sekitar $5.5 \mathrm{mg} / \mathrm{l}$ dan pada titik keluar sekitar $3 \mathrm{mg} / \mathrm{l}$. Bitton (1994) proses biofiltrasi dalam reaktor pertumbuhan melekat (attached growth reactor) supaya dapat bekerja dengan baik oksigen terlarut harus dijaga antara 2-5 $\mathrm{mg} / \mathrm{l}$.

Syarat oksigen terlarut yang diperlukan dalam proses biofiltrasi mencukupi mikroorganisma untuk melakukan penguraian senyawa organik, walaupun mendekati syarat minimal. Suhu operasi reaktor biofilter antara 28.2-28.7 dan $\mathrm{pH}$ antara 7.1-7.5 adalah kondisi yang baik untuk aktifitas mikroorganisma pengurai.[3] Inhibitor tidak teridentifikasi di dalam sistem, faktor penghambat yang menghalangi lapisan biofilm kontak dengan air baku kemungkinan bisa terjadi dari pengendapan tanah halus, lempung dan pasir halus yang menutupi sebagian lapisan biomasa (biofilm). Lempung dan tanah halus yang tersuspensi di dalam air baku kirakira berukuran $10^{-2} \mathrm{~mm}$ dapat mengendap sedalam 1 m dalam waktu 2 jam.[5]

Penurunan efisiensi penyisihan senyawa organik di dalam reaktor biofilter pada variasi suplai udara 0-10 liter/menit dapat dikatakan akibat tertutupnya biofilm yang menempel pada media oleh tanah halus dan lempung sehingga luas kontak antara biofilm dengan air baku berkurang, sehingga mikrooganisma tidak dapat bekerja dengan baik.

Fungsi suplai udara pada reaktor biologis melekat sebagai suplai oksigen untuk mendukung mikroorganisma melakukan penguraian substrat juga digunakan untuk menjaga kestabilan biofilm dari gangguan material yang menghalangi lapisan biomasa, merontokkan biofilm yang telah mati.

\subsubsection{Pengaruh Beban Organik Terhadap Efisiensi Penyisihan Zat Organik}

Beban organik adalah jumlah senyawa organik yang dapat diolah dalam reaktor biofilter per satuan 
luas permukaan media per satuan waktu, yang dinyatakan sebagai berat organik persatuan volume media perhari. Laju pembebanan senyawa organik pada waktu tinggal hidrolis 1-4 jam adalah $5.7,2.7$, 1.8 dan $1.5 \mathrm{~g} / \mathrm{m}^{2}$ media.hari, dengan efisiensi penyisihan adalah 49\%, 70\%, 73\%, dan $75 \%$. Penurunan waktu tinggal hirolis diikuti oleh penurunan efisiensi penyisihan, peningkatan debit air baku dan laju pembebanan senyawa organik. Penurunan waktu tinggal hidrolis mengakibatkan debit air baku meningkat sehingga beban hidrolis juga meningkat, sebagai akibatnya efisiensi penyisihan senyawa organik mengalami penurunan. Hubungan antara laju pembebanan dengan efisiensi penyisihan senyawa organik dalam reaktor biofilter bermedia plastik tipe srang tawon dengan luas permukaan 226 $\mathrm{m}^{2} / \mathrm{m}^{3}$ dapat dilihat pada Gambar 13 .

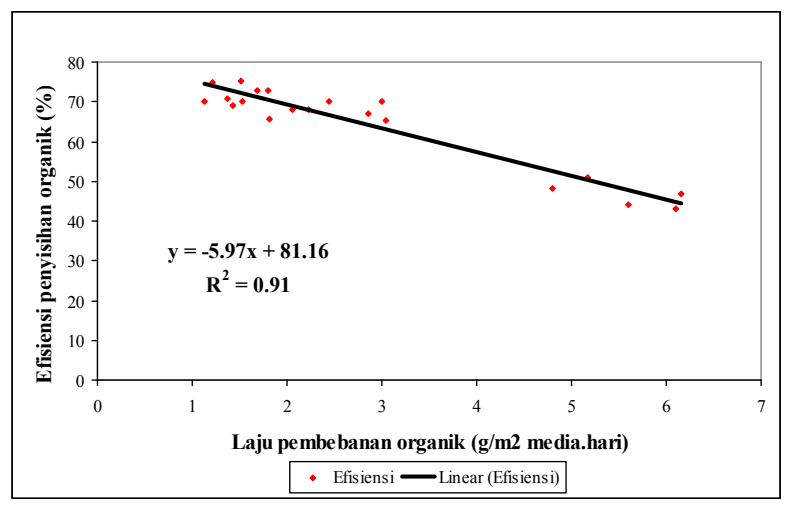

Gambar 13 : Hubungan Laju Pembebanan Dengan Efisiensi Penyisihan Organik.

Berdasarkan grafik diatas didapat persamaan hubungan antara laju pembebanan dengan efisiensi penyisihan senyawa organik, yaitu:

$y_{0}=-5.97 x_{0}+81.16$

dengan $R^{2}=0.91$

dimana:

$\mathrm{y}_{\mathrm{o}}=$ Efisiensi penyisihan senyawa organik (\%)

$\mathrm{x}_{\mathrm{o}}=$ Laju pembebanan senyawa organik $\left(\mathrm{g} / \mathrm{m}^{2}\right.$ media/hari)

Grafik dan persamaan diatas memperlihatkan hubungan laju pembebanan dengan efisiensi penyisihan senyawa organik merupakan suatu hubungan yang linier. Berdasarkan persamaan tersebut di atas dengan laju pembebanan senyawa organik antara 1.5 sampai dengan $6 \mathrm{~g} / \mathrm{m}^{2}$ media/hari diperoleh efisiensi penyisihan antara 45 sampai dengan $72 \%$.

\subsection{Penghilangan Fe, Mn dan Kekeruhan}

Berdasarkan hasil percobaan tersebut di atas dengan menggunakan proses biofilter dengan media plastik tipe sarang tawon dapat juga menghilangkan zat besi (Fe), mangan ( $\mathrm{Mn}$ ), dan kekeruhan yang ada di ada air dengan cukup baik. Konsentrasi zat besi, mangan dan kekeruhan yang ada di dalam air sungai selama percobaan rata-rata $0.94,0.53$, dan $0.6 \mathrm{mg}$ per liter. Setelah pengolahan menggunakan biofilter dengan WTH 2 jam dan suplai udara 20 liter per menit terjadi penurunan konsentrasi besi, mangan dan kekeruhan sebesar 0.31, 0.16 dan $16.5 \mathrm{mg}$ per liter dengan demikian efisiensinya adalah 67, 69 dan $73 \%$. Penyisihan besi, mangan dan kekeruhan secra lengkap dapat dilihat pada gambar 14 sampai 16

Zat besi dan mangan adalah salah satu senyawa yang dapat bereaksi dengan senyawa khlor, oleh karena itu di dalam proses pengolahan air minum jika konsentrasi zat besi cukup tinggi maka konsumsi senyawa klor menjadi besar pula, dan akibatnya selain biaya pengolahan bertambah besar karena konsumsi klor bertambah maka kemungkinan terbentuknya senyawa trihalomethan juga semakin besar pula.

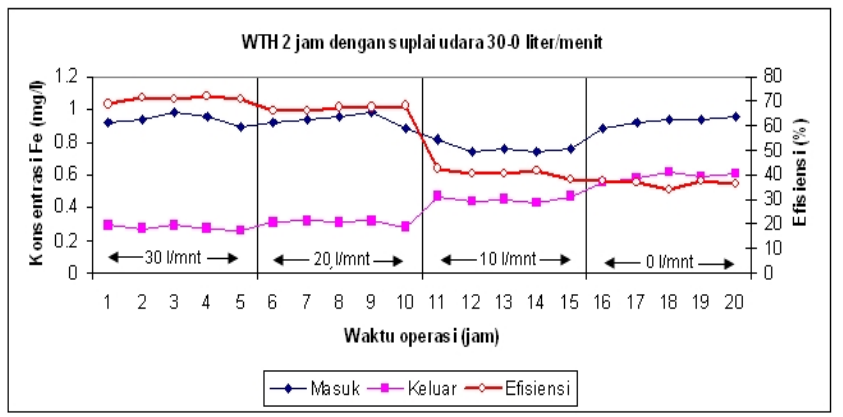

Gambar 14 : Penyisihan Besi Dengan WTH 2 Jam Dan Suplai Udara 0-30 Liter/Menit.

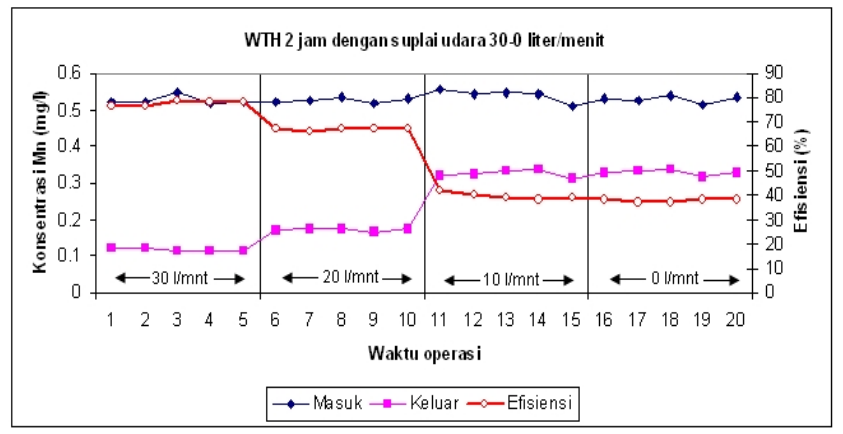

Gambar 15 : Penyisihan Mangan Dengan WTH 2 Jam Dan Suplai Udara 0-30 Liter/Menit. 


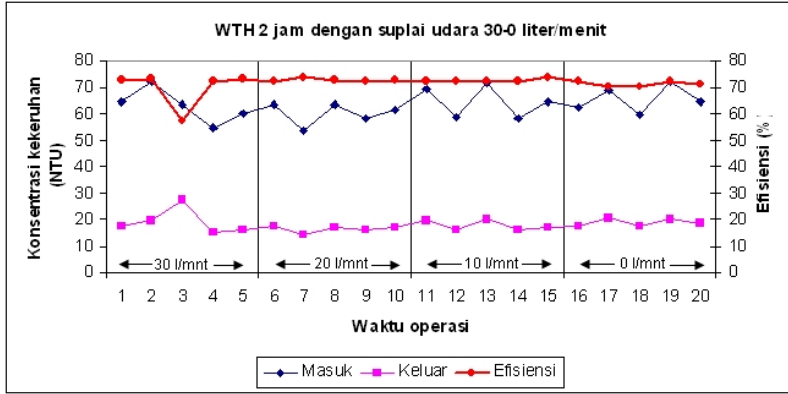

Gambar 16: Penyisihan Kekeruhan Dengan

WTH 2 Jam Dan Suplai Udara

0-30 Liter/Menit.

\section{PENGOLAHAN AIR MINUM DENGAN KOMBINASI PROSES BIOLOGI DAN MEMBRAN}

\subsection{Teknologi Membran di dalam Pengolahan Air}

Teknologi membran dalam pengolahan air berkembang dengan pesat dengan tingkat penyaringan atau sering disebut dengan istilah 'Filtration degree" yaitu micro filtration (MF), ultra filtration (UF), nano filtration (NF), hyper filtration/ reverse osmosis (RO). Distribusi ukuran partikel yang dapat dipisahkan sesuai dengan tingkatan proses filtrasi membran dapat dilihat pada Gambar 17.[5]

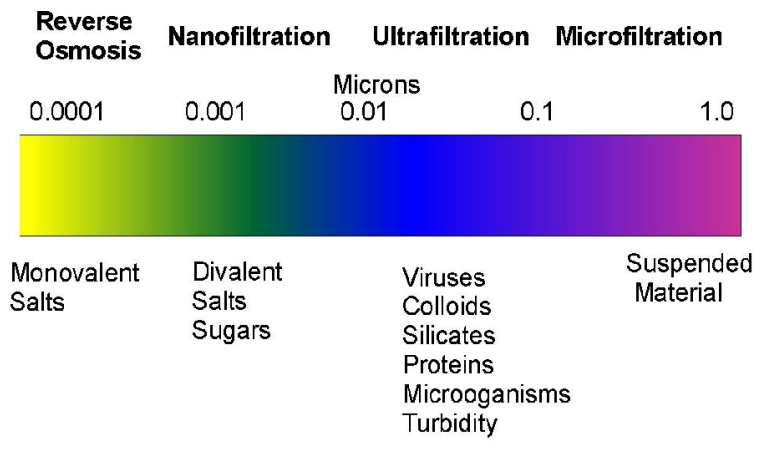

Gambar 17 : Tingkatan filtrasi di dalam proses membran.

Sesuai dengan tingkat penyaringan membran, aplikasi teknologi membran untuk tujuan pengolahan dengan kualitas yang dikehendaki dapat disesuaikan dengan tingkat filtrasi. Misalnya pada Micro Filtration / MF dengan derajad penyaringan (Filtration Degree) 1 micron, diharapkan sebagian besar dari padatan tersuspensi (suspended material) tersaring, sehingga sangat dimungkinkan merubah air laut menjadi air tawar, yaitu dengan menggunakan membran Reverse Osmosis (RO).[7]

Ultrafiltrasi adalah metoda pemisahan dengan menggunakan membran untuk menghilangkan zat terlarut dengan bobot molekul (BM) tinggi, beberap jenis koloid, mikroba sampai padatan tersuspensi di dalam air. Ultrafiltrasi memisahkan molekul terlarut berdasarkan ukuran pori yang berukuran 0.01 mikron dengan tekanan operasi 1-2 bar.Ultrafiltrasi memiliki keunggulan dibandingkan dengan metode lainnya yaitu jumlah produk yang dihasilkan cukup tinggi per satuan waktu proses yang sama, pemasangan alat yang relatif mudah, simpel dan kemudahan untuk membersihkan atau perawatan.[7]

Perencanaan kapasitas pengolahan menggunakan ultrafiltrasi ditentukan dari ukuran dan jumlah membran. Beberapa ukuran membrane ultrafiltrasi yang tersedia dapat dilihat pada table 7 .

Tabel 7 : Ukuran Dan Kapasitas Membran Ultrafiltrasi.

\begin{tabular}{cc}
\hline \multicolumn{2}{c}{ Modul ultrafiltrasi } \\
\hline Ukuran (inch) & Kapasitas $\left(\mathrm{m}^{3} /\right.$ jam) \\
\hline $4 \times 40$ & 0.5 \\
$6 \times 40$ & 0.75 \\
$8 \times 40$ & 1 \\
$10 \times 40$ & 1.5
\end{tabular}

Mutu air baku PAM yang semakin memburuk dan meningkatnya biaya pengolahan air bersih memerlukan teknologi alternatif dengan biaya murah, lahan yang dibutuhkan kecil dan kuantitas penyaringan besar namun kualitas memenuhi baku mutu yang disyaratkan. Mengkombinasikan proses biologi dengan membran ultra filtrasi adalah salah satu cara yang tepat untuk mendapatkan air minum dengan biaya operasional lebih murah, memperpendek proses pengolahan konvensional dan mendapatkan kualitas air hasil pengolahan yang lebih baik. Kombinasi proses biofilter dengan ultrafilrasi merupakan solusi untuk mengolah air baku PAM yang sudah tercemar limbah dan memberikan beberapa keuntungan antara lain mereduksi luasan atau area sampai $40 \%$, sistem yang jauh lebih kompak, dapat dioperasikan secara otomatis maupun manual serta konsistensi dan mutu air yang dihasilkan.

Pengolahan air permukaan yang sering digunakan saat ini adalah dengan menggunakan proses pengendapan kimia dan filter pasir cepat seperti yang terlihat pada Gambar 12 .

\subsection{Pengolahan Air Minum dengan Proses Biofiltrasi dan Ultrafiltrasi}

Unit ultrafiltrasi menggunakan modul membrane tipe hollow fiber dengan ukuran modul $6 \mathrm{x}$ 40" dengan ukuraran pori 0.01 mikron. Pilot plant kombinasi biofiltrasi dengan ultrafiltrasi (UF) diperoleh alternatif teknologi air yang mampu menurunkan kandungan zat organik, amoniak, besi, mangan dan kekeruhan tanpa menggunakan bahan 
kimia seperti pada proses konvesional. Rancangan kombinasi proses biofiltrasi dengan ultra filtrasi dalam pengolahan air dapat dilihat sepertri pada Gambar 19 (Lampiran) dan aplikasi dalam penelitian dapat dilihat pada gambar 20 .

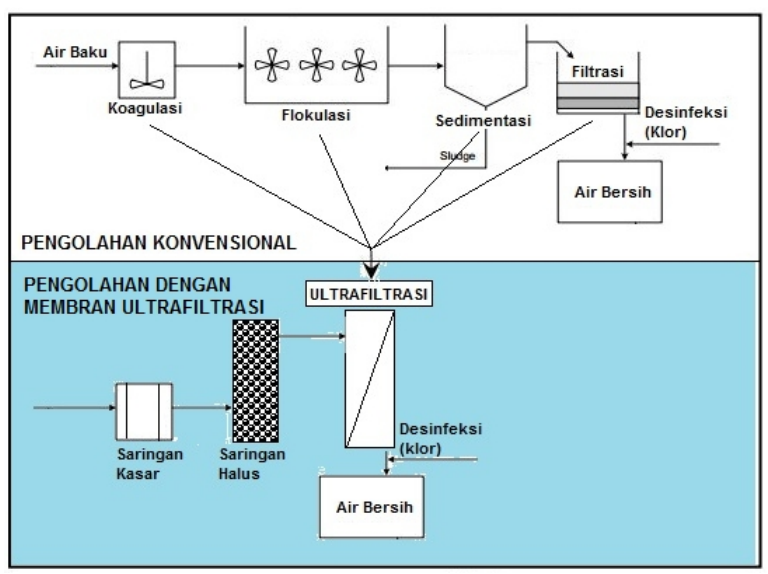

Gambar 18 : Perbandingan Proses Konvensional Dengan Membrane Ultra Filtrasi Dalam Pengolahan Air[7].

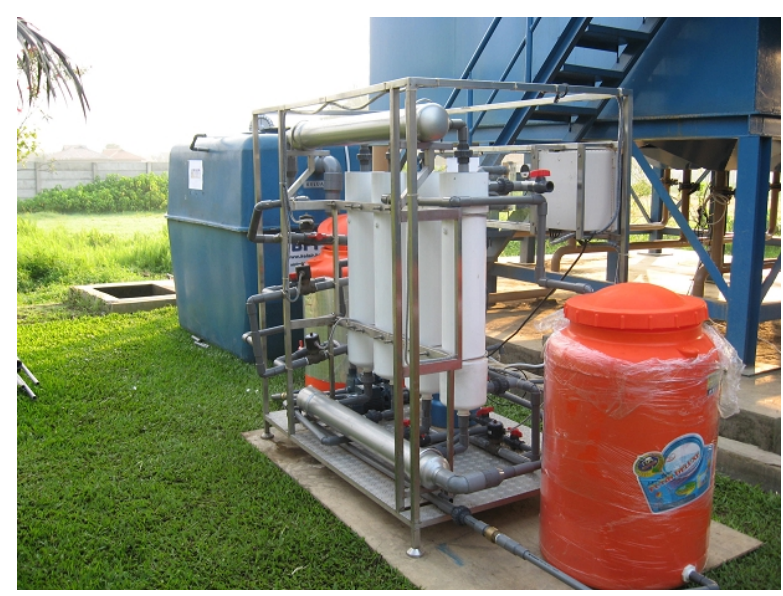

Gambar 20 : Pilot Plant Kombinasi Biofilttrasi Dengan Ultrafiltrasi.

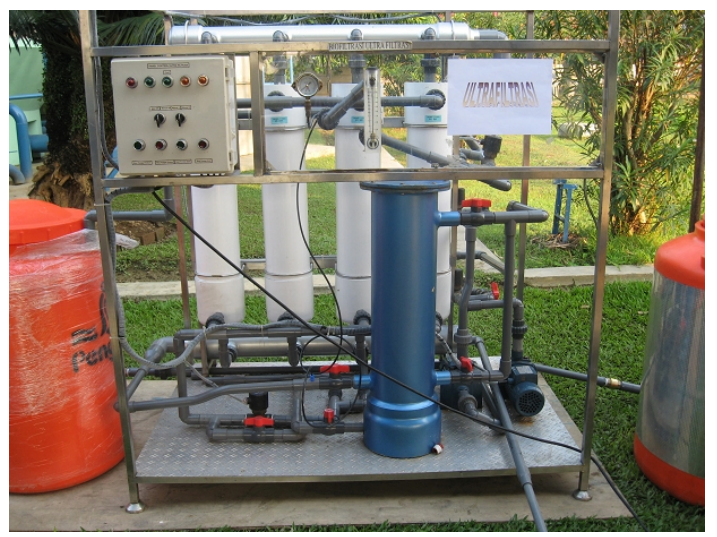

Gambar 21 : Unit Ultrafiltrasi.
Air baku dari saluran intake dipompa ke reaktor biofilter dengan menggunakan pompa air baku. Reaktor biofilter diisi dengan media biofilter dari bahan plastik tipe sarang tawon. Di dalam reaktor biofilter tersebut senyawa polutan yang ada di dalam air baku misalnya zat organik, amoniak, zat besi, mangan, deterjen dan senyawa polutan lain dapat diuraikan secara biologis. Selain itu padatan tersuspensi yang ada di dalam air baku dapat diendapakan. Air yang keluar dari biofilter selanjutnya di tampung ke bak penampung, selanjutnya dipompa ke automatik filter yang dapat menyaring kontoran sampai 10-50 mikron. Dari filter automatik air dilairkan ke unit ultrafiltrasi yang dapat menyaring sampai ukuran 0,01 mikron.[4]

. Air yang keluar dari unit ultra filtrasi dilairkan ke bak penampung air olahan sambil diinjeksi dengan larurtan kaporit untuk proses disinfeksi dan selanjutnya dilairkan ke bak penampung air bersih.

Dengan sistem kombinasi biofiltrasi dan ultra filtrasi mempunyai beberapa kelebihan antara lain adalah :

- Penggunaan proses biofiltrasi dapat menghilangkan senyawa polutan yang tidak bisa dihilangkan dengan proses konvensional misalnya, zat organik, amoniak, deterjen, pestisida, dll. Senyawa tersebut dapat diuraikan dengan proses biologis secara alami (natural).

- Tekanan operasional rendah antara 1-2 bar sehingga biaya proses rendah

- Tanpa menggunakan bahan koagulan dan flokulan. Dalam hal ini bahan yang digunakan hanya larutan kaporit untuk mendapatkan konsentrasi sisa klor yang cukup agar tidak terjadi rekontaminasi.

- Dengan proses ultra filtrasi dapat dihasilkan air olahan dengan kualitas yang sangat baik dan stabil.

- Bentuknya lebih kompak sehingga luas area yang dibutuhkan lebih kecil.

- $\quad$ Sangat fleksibel jika ada penambahan kapasitas

\section{KESIMPULAN}

Dari hasil penelitian pengolahan air minum dengan mengkombinasikan proses biofiltrasi dengan ultrafiltrasi menggunakan biofilter tercelup dengan media plastik sarang tawon dapat disimpulkan beberapa hal sebagai berikut :

- WTH semakin pendek laju pembebanan semakin besar dan efisiensi penyisihan amonia semakin kecil.

- Kondisi operasi terpilih pada WTH 2 jam dan suplai udara 20 liter/menit dengan efisiensi penyisihkan amoniak, organik, besi, mangan 
dan kekeruhan masing-masing 65\%, $68 \%, 65 \%$, $68 \%, 67 \%$ and $72 \%$

- Pengolahan air baku PAM dengan penerapan proses biofiltrasi dengan media plastik tipe sarang tawon menghasilkan air olahan memenuhi kriteria mutu air golongan I [12] sebagai air baku PAM dan dengan mengkombinasikan dengan proses ultrafiltrasi menghasilkan air olahan memenuhi kriteria sebagai air minum.[13]

- Rekomendasi disain reaktor biofilter:

Basis = Laju pembebanan amoniak

Suhu operasi $(\mathrm{T})=28-30{ }^{\circ} \mathrm{C}$

Tekanan operasi $(\mathrm{P})=1 \mathrm{~atm}$

$\mathrm{pH}$ operasi $(\mathrm{pH})=6.8-7.5$

Media biofilter :

Bahan = Plastik

Tipe = Sarang tawon

$\mathrm{WTH}=2$ jam

Suplai udara terpilih (Qu)

$$
=0,1035 \mathrm{lpm} / \mathrm{m}^{2} \text { media }
$$

Laju pembebanan amoniak $\left(\mathrm{NH}_{4}-\mathrm{N}\right)$ (La)

$$
=0.2 \mathrm{~g} / \mathrm{m}^{2} \text { media.hari }
$$

Persamaan regresi laju pembebanan dan efisiensi penyisihan amoniak :

$$
y_{a}=-91.19 x_{a}+77.12\left(R^{2}=0.92\right)
$$

- Disain kapasitas pengolahan ultrafiltrasi dihitung berdasarkan ukuran modul yang digunakan dikalikan jumlah modul:

- Kombinasi biofiltrasi dengan ultra filtrasi mempunyai beberapa kelebihan, yaitu mampu menyisihkan amoniak, organik, deterjen dan pestisida yang tidak dapat dihilangkan melalui proses konvensiona, sedangkan oksida warna, besi, mangan dan logam-logam lainnya serta kekeruhan disisihkan di membran ultrafiltrasi.

- Kombinasi proses biofiltrasi dengan ultra filtrasi mampu mereduksi biaya operasional karena dalam mengolah air baku PAM dilakukan tanpa menggunakan bahan koagulan dan flokulan. Penggunaan klor hanya untuk mendapatkan konsentrasi sisa khlor yang cukup sehingga tidak terjadi rekontaminasi.

\subsection{Saran}

- Suplai udara berpengaruh terhadap efisiensi penyisihan amoniak, organik, besi, mangan dan detergen sehingga perlu penerapan difuser udara dengan ukuran yang lebih halus untuk memperluas kontak antara air baku dengan udara.

- Penyisihan amoniak dan organik juga berlangsung pada kondisi tanpa suplai udara, untuk meningkatkan efisiensi penyisihan zat tersebut perlu mengkombinasikan proses biofiltrasi secara aerobik dengan anaerobik.
- Perlu dilakukan penyempurnaan proses pengendapan awal, untuk mengurangi padatan tersuspensi yang dapat mengganggu kontak antara lapisan biofilm dengan air baku.

\section{DAFTAR PUSTAKA}

1. Badan Pusat Statistik (BPS). 2013. Persentase Rumah Tangga Menurut Provinsi dan Sumber Air Minum.

2. Bitton, G. 1994. Wastewater Microbiology. Willey-Liss. New York.

3. Casey, T.J.(1997). “Unit Treatment Process In Water and Wastewater Engineering". University College Dublin, Ireland : John wiley and Sons Ltd

4. Chaturvedi, B. K., Ghoshb, AK., Ramachandhranb, V., Trivedi, M.K., HanTab, M. S., Misrab, B.M. (2001) Preparation, characterization and performance of polyethersulfone ultrafiltration membranes, Desalina- tion, 133, 31-40.

5. Degremont. 1991. Water Treatment Handbook. $6^{\text {th }}$ edition. Lavoiser Publishing. Paris

6. Grady, C.P.L., and H.C. Lim. 1980. Biological Wastewater Treatment: Theory\& Application. Marcell Dekker.Inc. New York.

7. Guo, X., Z. Zhang, L. Fang, L. Su. 2009, Study on Ultrafiltration for Surface Water by Polyvinylchloride hollow Fibre Membrane, Desalination, Vol. 238 (1-3), p. 183-119

8. Hong HC, Wong $\mathrm{MH}$ and Liang Y. 2012. Amino acids as precursors of trihalomethane and haloacetic acid formation during chlorination. Archives of Environmental Contamination and Toxicology 5, 344-352.

9. Horan, N.J.(1990). "Biological Wastewater Treatment systems : Theory and Operation". University of Leeds, England. John Wiley \& Sons Ltd.

10. Jennings, J.R. 1991. Catalytic Ammonia Syntesis:Fundamentals and Practice. Plenum Press. New York.

11. Metcalf and Eddy. 2003. Wastewater Engineering: Treatment and Reuse. $4^{\text {th }}$. Mc Graw Hill.Singapore.

12. Peraturan Pemerintah Republik Indonesia (PPRI) No. 82 Tahun 2001. tentang Pengelolaan Kualitas Air dan Pengendalian Pencemaran Lingkungan. Jakarta

13. Peraturan Menteri Kesehatan Republik Indonesia No. 492/Menkes/Per/IV/2010. Tentang Persyaratan Kualitas Air Minum.

14. Rochmah S. 2010. Analisis Kepuasan Pelanggan Terhadap Kualitas Pelayanan 
Perusahaan Daerah Air Minum.Fakultas IImu Administrasi Unbraw.

15. Rosa, M.F., A.A.L. Furtado, R.T. Albuquerque, S.G.F. Leite, and R.A. Medronho.1998. Biofilm development and ammonia removal in nitrification a saline wastewater. Bioresource Technology 65: 135-138.

16. Rook JJ. (1974). Formation of haloforms during chlorination of natural waters. Water Treatment Examination 23, 234-243.

17. Singer PC and Chang SD. 1989. Correlation between trihalomethanes and total organic halides formed during water treatment. J. Am. Wat. Wks Assoc., 81, 8-17

18. Said, N.I. 2000. Pengolahan Air Limbah dengan Proses Biofilter Anaerob-Aerob. Jurnal Teknologi Lingkungan Volume 1 No.1. Jakarta
19. Stevens A, Moore LA, Slocum CJ et al. 1989. By-product of chlorination at ten operating utilities. In Water Chlorination: Chemistry, Environmental Impact and Health Effects, Ann Arbor Science 6, 579-604

20. Wang W, Ye B, Yang L et al. 2007. Risk assessment on disinfection by-products of drinking water of different water sources and disinfection processes. Environment International 33, 219-225.

21. Watten, B.J., and P.L.,Sibrell. 2006. Comparative performance of fixed-film biological filters: Application of reactor theory. Aquacultural Engineering 34: 198213

22. Winkler, M.A. 1981. Biological Treatment of Wastewater. John Willey and Sons. New York. 


\section{LAMPIRAN}

Tabel 6 : Analisa Laboratorium Air Hasil Pengolahan Biofiltrasi Dan Ultrafiltrasi

\begin{tabular}{|c|c|c|c|c|c|c|c|c|c|}
\hline \multirow{3}{*}{$\begin{array}{l}\text { No } \\
\text { A }\end{array}$} & \multirow{2}{*}{ Parameter } & \multirow{3}{*}{ Satuan } & \multirow{3}{*}{$\begin{array}{c}\text { Baku mutu } \\
{[12]}\end{array}$} & \multirow{3}{*}{$\begin{array}{c}\text { Baku mutu } \\
{[13]}\end{array}$} & \multirow{3}{*}{ Air baku } & \multicolumn{4}{|c|}{ Hasil pengolahan } \\
\hline & & & & & & \multirow[t]{2}{*}{ Biofilter } & \multirow[t]{2}{*}{ Ultrafiltrasi } & \multicolumn{2}{|c|}{ Keterangan } \\
\hline & FISIKA & & & & & & & [12] & [13] \\
\hline 1 & Bau & - & Tdk.berbau & Tdk berbau & berbau & Tdk berbau & Tdk berbau & $\mathrm{V}$ & $\mathrm{V}$ \\
\hline 2 & Zat padat terlarut (TDS) & $\mathrm{mg} /$ & 1500 & 500 & 125 & 120 & 120 & v & v \\
\hline 3 & Kekeruhan & NT & 25 & 5 & 60 & 16 & $<1$ & v & v \\
\hline 4 & Rasa & $\cdot$ & Normal & Normal & Normal & Normal & Normal & v & v \\
\hline 5 & Suhu $\left.(\operatorname{lab})^{* *}\right)$ & $\stackrel{\circ}{\circ}$ & - & - & 27.1 & 27,1 & 27,1 & V & v \\
\hline 6 & Warna $* *)$ & Pt-Co & 50 & 15 & 20 & 10 & $<1$ & $\mathrm{v}$ & v \\
\hline B. & KIMIA & & & & & & & & \\
\hline 1 & Air Raksa (Hg) & $\mathrm{mg} /$ & 0,001 & 0.001 & 0.001 & $<0,0005$ & $<0.0005$ & v & v \\
\hline 2 & Arsen (As) & $\mathrm{mg} /$ & 0,05 & 0.01 & 0.01 & $<0,005$ & $<0.005$ & v & v \\
\hline 3 & Besi $(\mathrm{Fe})^{* *}$ ) & $\mathrm{mg} /$ & 1,0 & 0.3 & 0.9 & 0,564 & $<0.003$ & v & $\mathrm{v}$ \\
\hline 4 & Fluorida $\left.(\mathrm{F})^{* *}\right)$ & $\mathrm{mg} /$ & 1,5 & 1.5 & 0.5 & 0,39 & 0.04 & V & $\mathrm{v}$ \\
\hline 5 & Kadmium $(\mathrm{Cd}) * *$ ) & $\mathrm{mg} /$ & 0,005 & 0.003 & 0.002 & $<0,002$ & $<0.002$ & v & $\mathrm{v}$ \\
\hline 6 & Kesadahan total $\left.\left(\mathrm{CaCO}_{3}\right) * *\right)$ & $\mathrm{mg} /$ & 500 & 500 & 120 & 117 & 91 & v & $\mathrm{v}$ \\
\hline 7 & Khlorida $(\mathrm{Cl}) * *$ ) & $\mathrm{mg} /$ & 600 & 250 & 115 & 11 & 10 & V & v \\
\hline 8 & Khromium heksavalen $\left.(\mathrm{Cr} \mathrm{VI}){ }^{* *}\right)$ & $\mathrm{mg} /$ & 0,05 & 0.05 & 0.01 & $<0,01$ & $<0.003$ & $\mathrm{v}$ & $\mathrm{v}$ \\
\hline 9 & Mangan $(\mathrm{Mn}) * *$ ) & $\mathrm{mg} /$ & 0,5 & 0.4 & 0.5 & 1.3 & $<0.003$ & v & v \\
\hline 10 & Nitrat $\left.\left(\mathrm{NO}_{3}-\mathrm{N}\right){ }^{* *}\right)$ & $\mathrm{mg} /$ & 10 & 50 & 1.2 & 10,4 & 3 & v & v \\
\hline 11 & Nitrit $\left.\left(\mathrm{NO}_{2}-\mathrm{N}\right){ }^{* *}\right)$ & $\mathrm{mg} /$ & 1,0 & 3 & 0.04 & 0,02 & $<0.002$ & v & v \\
\hline 12 & $\left.\mathrm{pH}\left(26^{\circ} \mathrm{C}\right) * *\right)$ & - & - & $6.5-8.5$ & 6.6 & 6,9 & 6.8 & v & v \\
\hline 13 & Selenium (Se) & $\mathrm{mg} /$ & 0,01 & 0.01 &, 0.002 & $<0,002$ & $<0.002$ & v & v \\
\hline 14 & Seng $(Z n) * *)$ & $\mathrm{mg} /$ & 15 & 3 & 1 & 0,386 & $<0.002$ & v & $\mathrm{v}$ \\
\hline 15 & Sianida $(\mathrm{CN}) * *)$ & $\mathrm{mg} /$ & 0,1 & 0.07 & 0.005 & $<0,005$ & $<0.005$ & v & v \\
\hline 16 & Timbal $\left.(\mathrm{Pb})^{* *}\right)$ & $\mathrm{mg} /$ & 0,05 & 0.005 & 0.05 & $<0,005$ & $<0.005$ & v & v \\
\hline 17 & Sulfat $\left.\left(\mathrm{SO}_{4}\right) * *\right)$ & $\mathrm{mg} /$ & 400 & 250 & 121 & 72,1 & 1 & $\mathrm{v}$ & $\mathrm{v}$ \\
\hline 18 & Surfactan anion (MBAS) & $\mathrm{mg} /$ & 0,5 & 0.05 & 0.2 & 0.05 & $<0.005$ & V & v \\
\hline 19 & Nilai Permanganat $\left.\left(\mathrm{KMnO}_{4}\right)^{* *}\right)$ & $\mathrm{mg} /$ & 10 & 1 & 19 & 7,3 & 0.2 & v & $\mathrm{v}$ \\
\hline 20 & Amonia & & 10 & 1.5 & 12 & 1.5 & 0.2 & v & $\mathrm{V}$ \\
\hline C & MIKROBIOLOGI & & & & & & & & \\
\hline 1 & Total Koliform & MPN/100ml & 50 & $<2$ & 100 & 20 & 0 & V & V \\
\hline
\end{tabular}

Keterangan: $\mathrm{V}=$ memenuhi baku mutu 


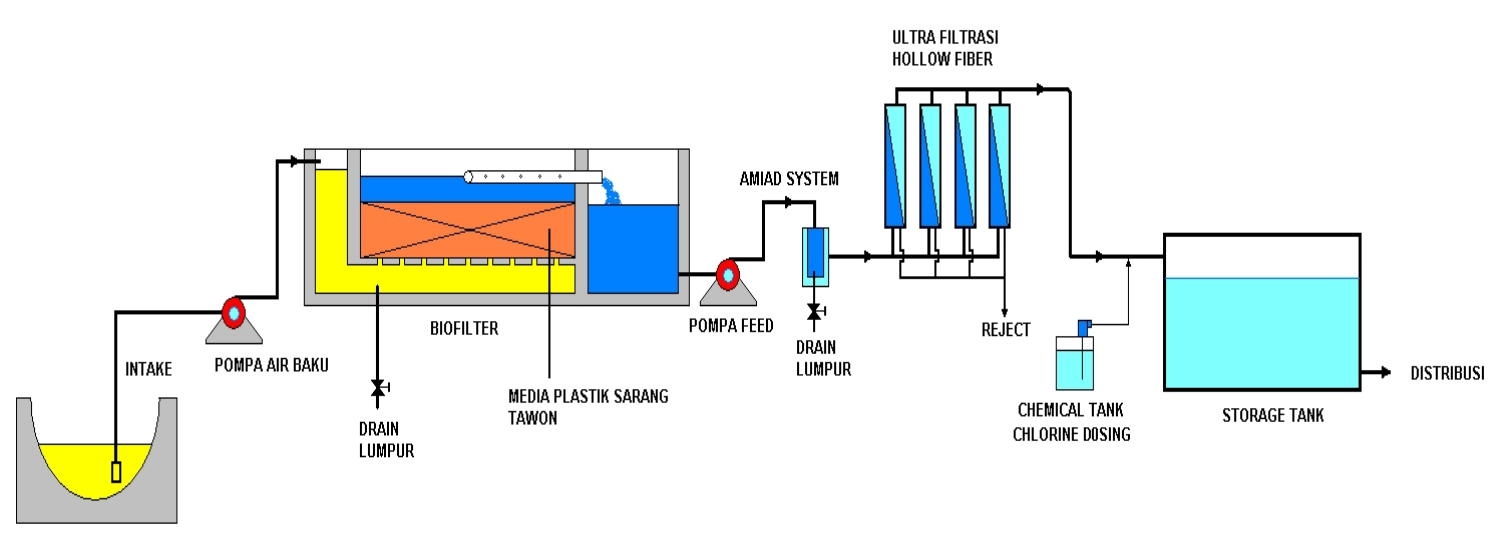

Gambar 19: Rancangan Proses Pengolahan Air Dengan Kombinasi Biofilttrasi Dan Ultrafiltrasi. 